\title{
اثر البيئة على رسوم الأطفال في منطقة عسير ( دراسة هقارنة )
}

\author{
اعلداد \\ آمالـ بنت عبدالله الشهري \\ محاضر بكلية التربية \\ جامعة نجران - المملكة العربية السعودية
}

مجلة بحوث التربية النوعية ـ جامعة المنصورة

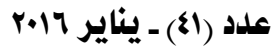


= اثرالبيئة على رسوم الاطفال مِ منطقة عسير ( دراسة مقارنة) 


\section{( دراسة هقارنة ) متسم}

إعداد

آمال بنت عبداللهالشهريكـ

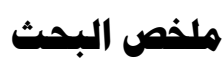

هدف البحث الى التعرف على عناصـر بيئسة منطقـة عسير والتي تظهر ِِّ تعبيرات الاطفـال

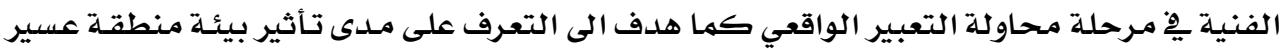

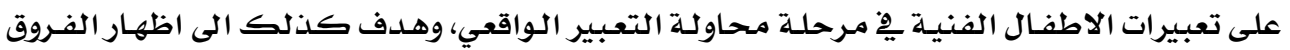

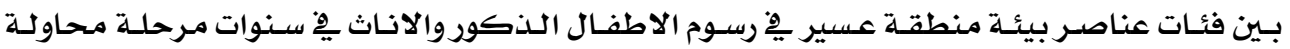

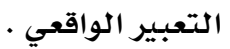

وتتلخص نتائج البحث على النحو التالي:

ا. اتضح للباحثة أن تأثير بيئة منطقة عسير على رسوم الاطفال يِّم مرحلة محاولة التعبير الواقعي

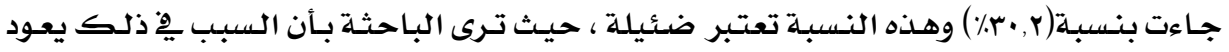

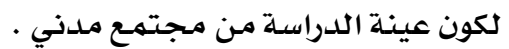

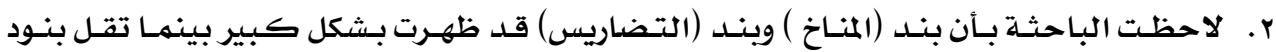

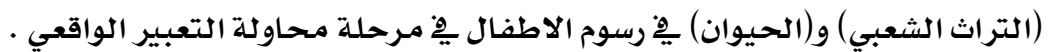

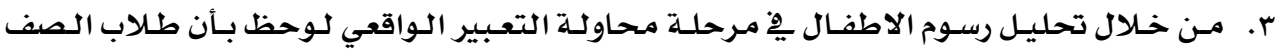

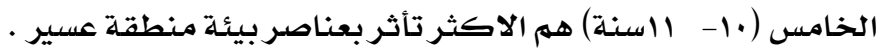

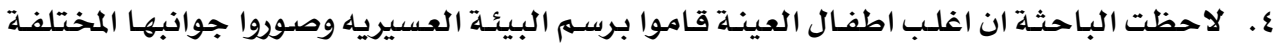

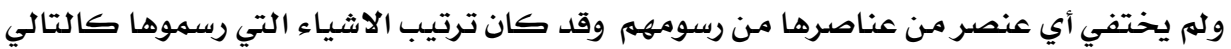

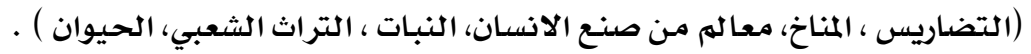

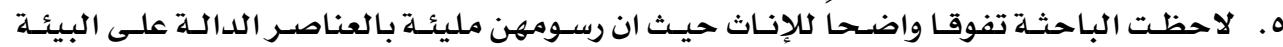

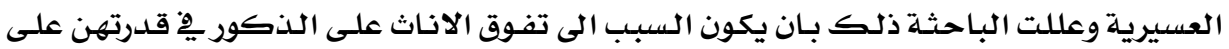

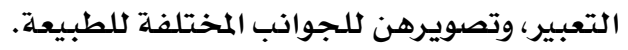


أن من نعم الله علينا ِِْ هذا الوطن الحبيب المملكة العربية السعودية اختلاف بيئاتها ومـن

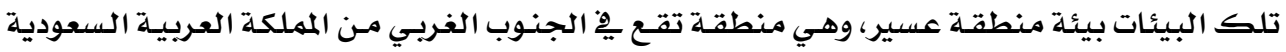

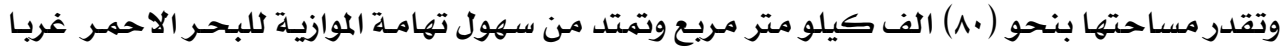

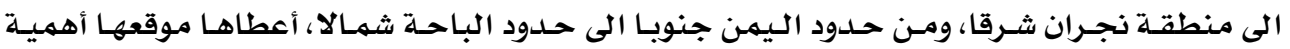

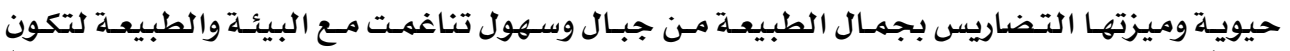

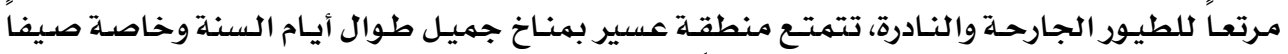

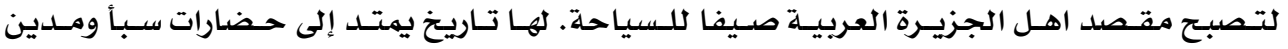

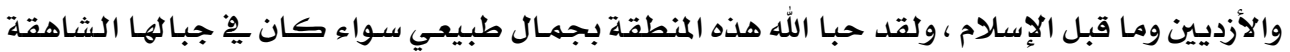

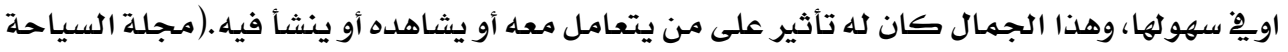

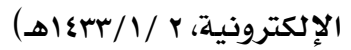

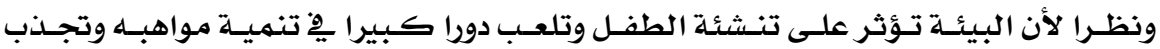

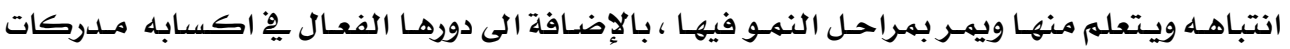

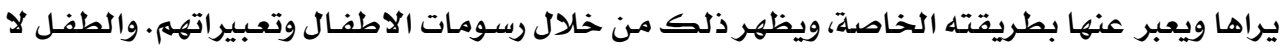

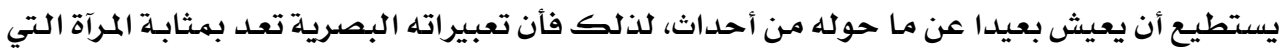

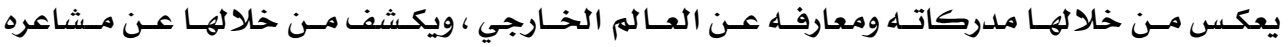

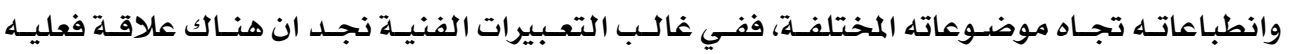

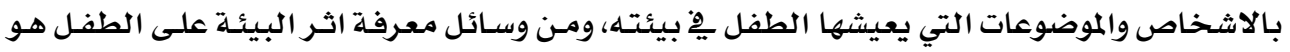

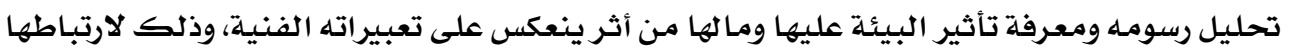
ارتباطا كاملا بما حول الطفل وبما يشاهده.

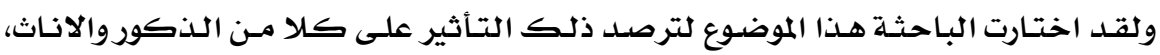

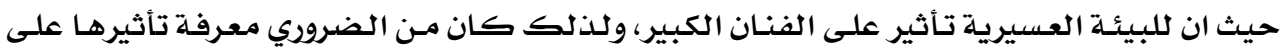

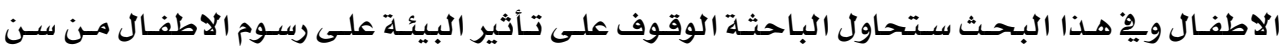

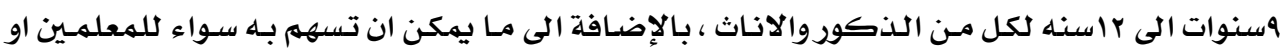

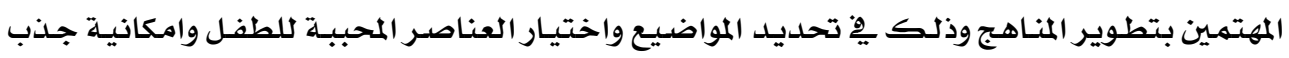

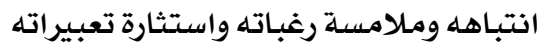

مشكلة البصث : nمثب

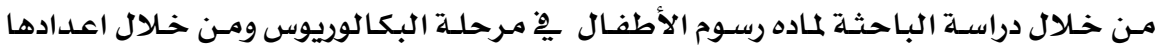

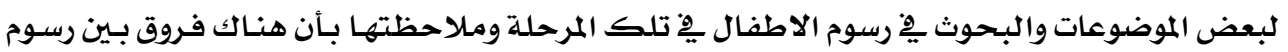

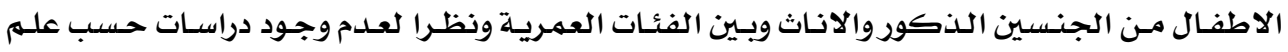

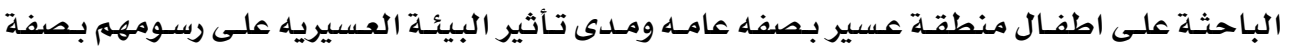




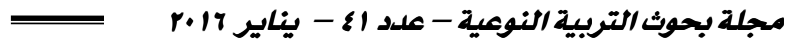

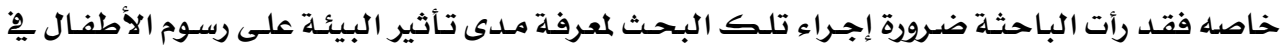

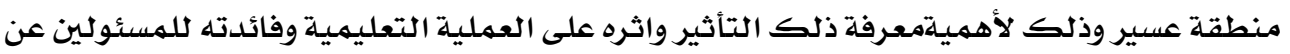

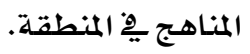

\section{وقد نبعت مشكلة البحث فى التساؤلات الأتية :-}

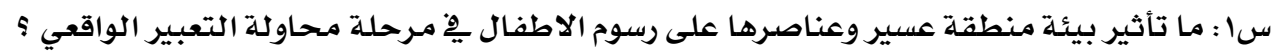

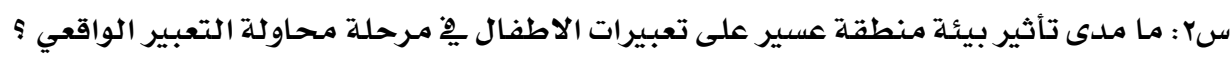

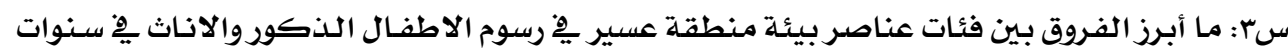

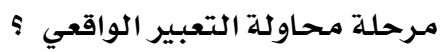
اهد|ف البحث : يهدف البحث الى:

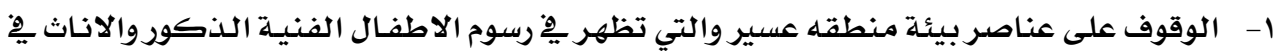

$$
\text { مرحلة محاوله التعبير الواقعي. }
$$

r- التعرف على مدى تأثير بيئة منطقه عسير على رسوم الاطفال الفنية الذكور والاناث يْ مرحلـة

$$
\text { محاولة التعبير الواقعي. }
$$

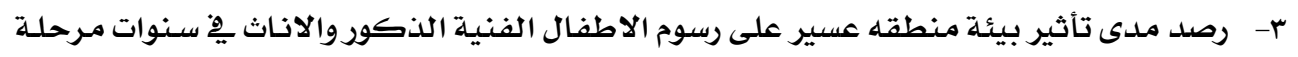
محاولة التعبير الواقعي.

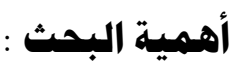

$$
\text { 1- التعرف على أثر البيئة على رسوم الاطفال الذكوروالاناث . }
$$

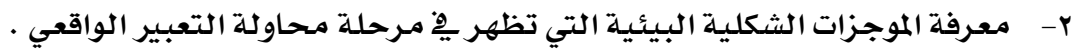

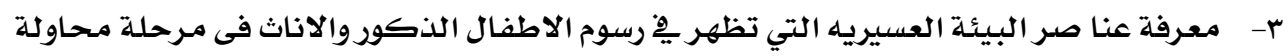

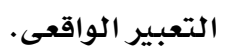

ع- تثقيف الطفل بصريا من خلال ريط رسومـه بالبيئة بطريقه محببـه وسليمها:

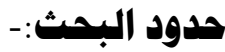

الموضوعية : اقتصار البحث على الاطفال الذكور والاناث من سن الند الى باسنه

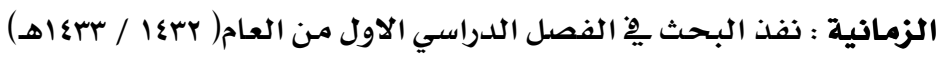

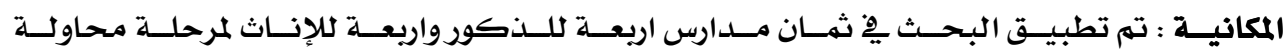

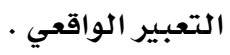




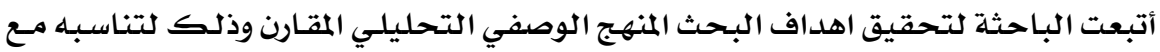

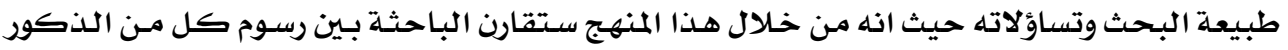

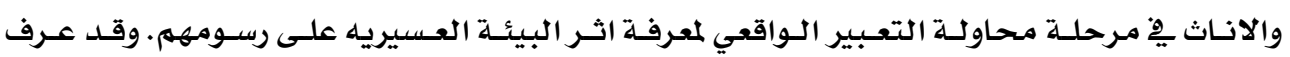

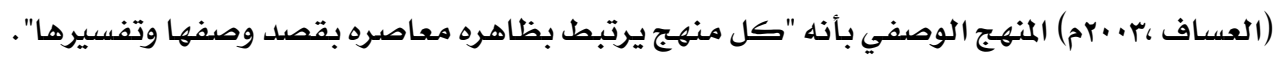

\section{هجتهع وعينة البحث :}

يتألف مجتمـع البحـث مـن جميـع طلاب وطالبـات منطقـه عسير لمرحلـة محاولـة التعبير

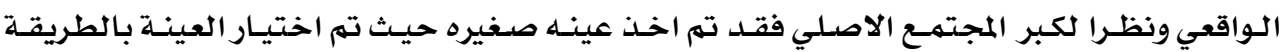

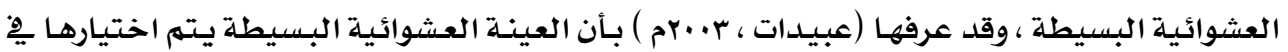

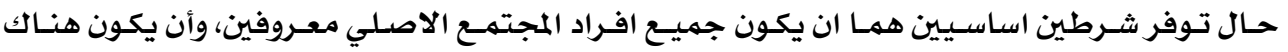
تجانس بين هؤلاء الأفراد.

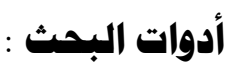
تم تصميم اسـتمارة تحتوي على فئسات لعناصـر البيئسة العسيريه لكل مـن الذذكوروالانـاث

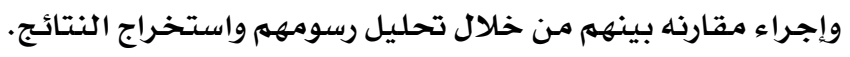

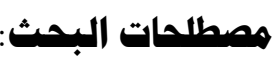
البيئة :

عرفها (عبدالكريهم، ؟991م) بأنها "الظروف المحيطة التي تؤثر فِ النمو والحياة وهي نوعان

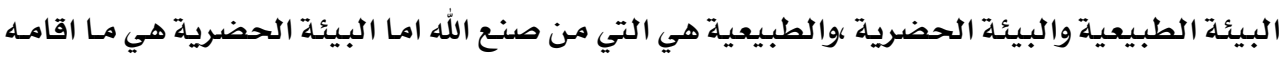

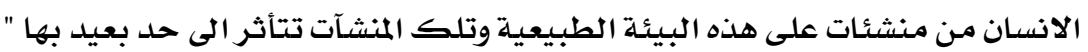
وقد عرفتها الباحثة تعريف اجرائي بانها اجمالي الاشياء التي تحيط بنا ويكون لها التأثير

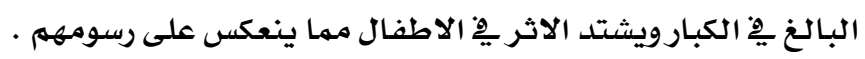
التفبير الفني عند الاطفال:

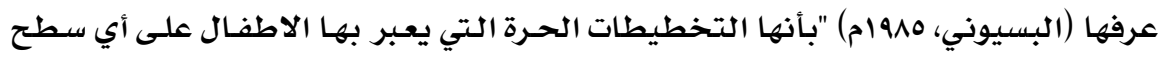

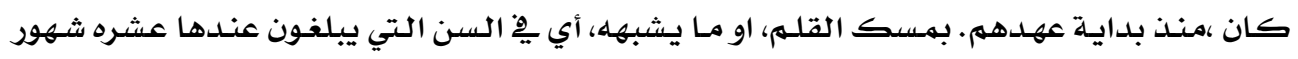

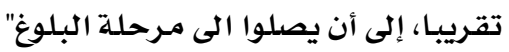

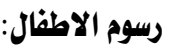

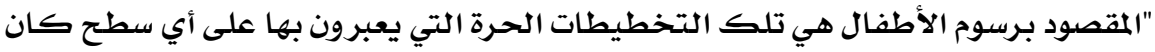

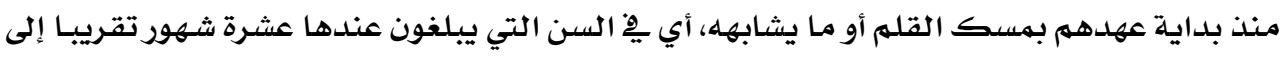




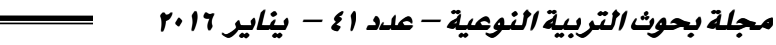

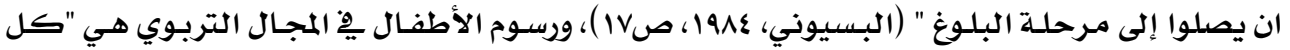

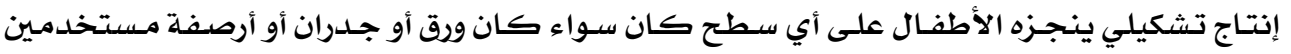

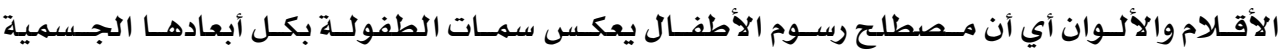

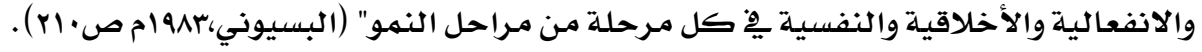

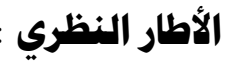

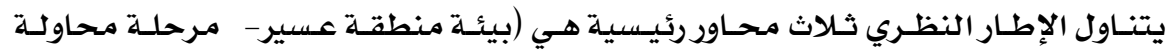

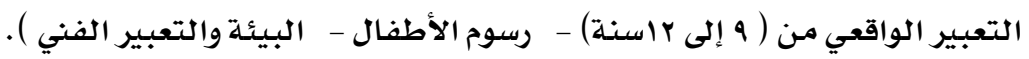

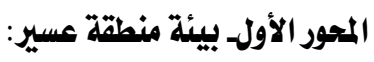

\section{تعريف البيئة:Environment"}

وعرفها (عبدالكريهم ع99ام) "بأنها الظروف المحيطة التي تؤثر يُ النهو والحياة وهي نوعان

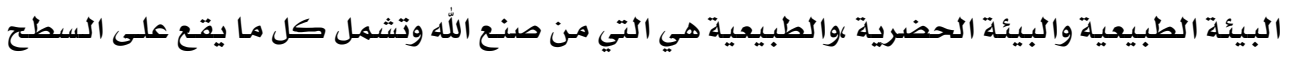

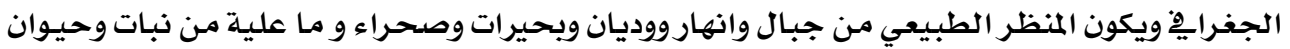

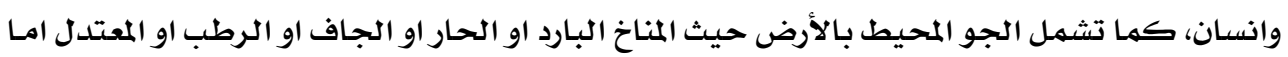

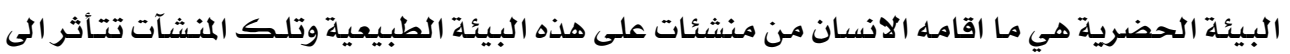

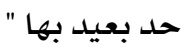

وقد يتناول المحور الاول عده محاوروهي :

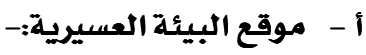

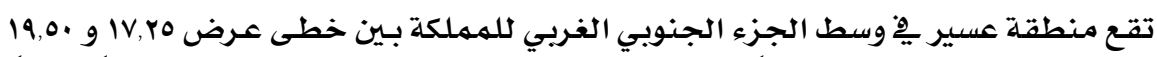

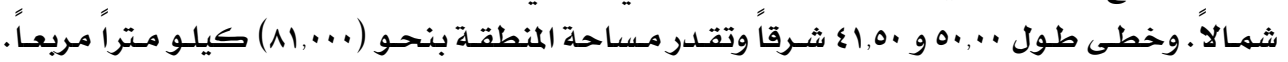

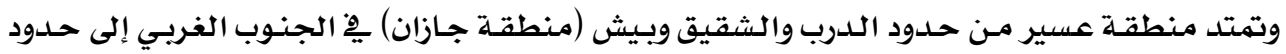

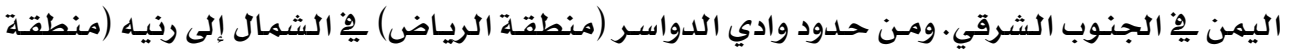

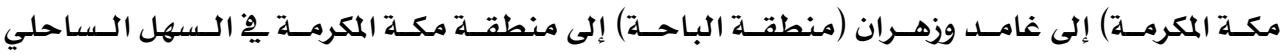

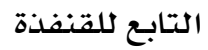

ب- تضاريسها :- تنقسم تضاريسها الى أربعة أنواع أساسية هي:1- (- مهامة الساحلية:-

وتشمل السهول السـاحلية المنبسطة والممتدة من سـاحل البحـر الاحمـر حتى بلدايـة مرتفعـات

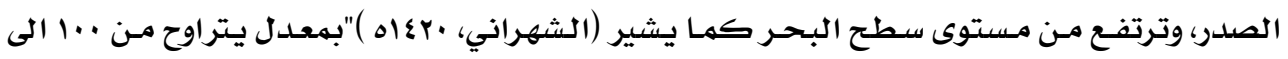

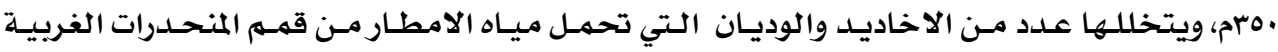


لسلسلة جبال السروات حيث تصب ِِّ البحر الاحمر" وتمتاز ارضـي هـذا الجـزاء مـن عسير بخصوبتها

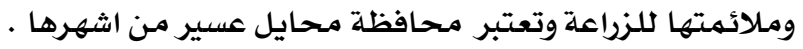

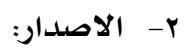

وتمتد من تهامـة السـاحلية الى مرتفعات السراة، ولأنها مرتفـع عن سطح البحـر فهـي قليلـة

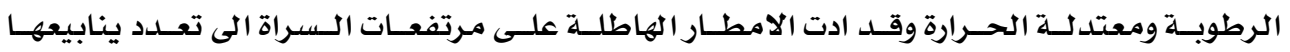

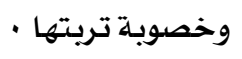

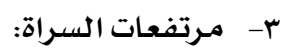

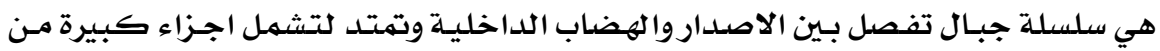

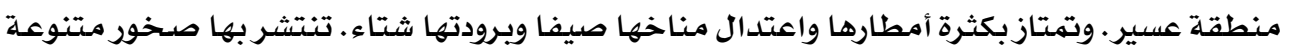

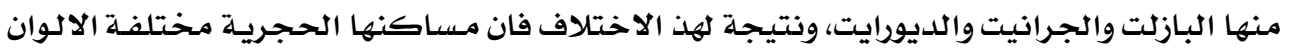

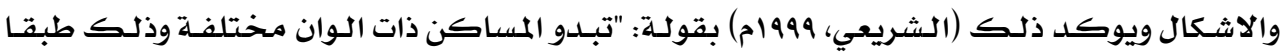

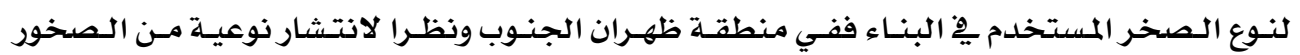

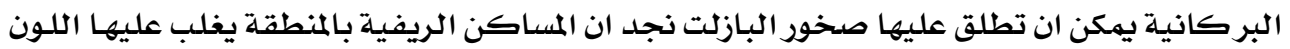

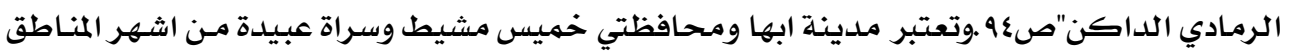
التي تمثلها .

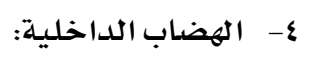

هي الهضاب الشرقية المنبسطة والتي تمتـد مـن مـرتفعـات السـراة حتى تقـترب مـن صـحراء

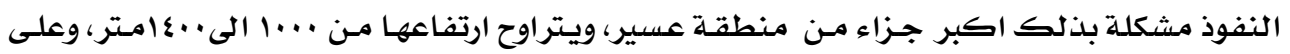

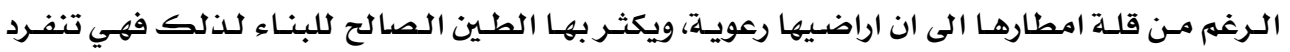

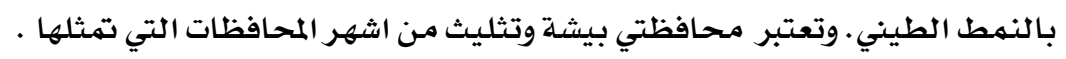
ت- معالم من صنع الانسان يِّ منطقة عسير: تقصد بـه الباحثة كل مـا بـرزوتميز مـن انشاء الانشاء سـواء كـان ذلك قصر مثل (قصر

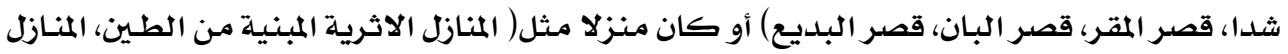

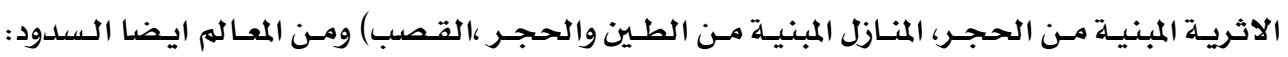

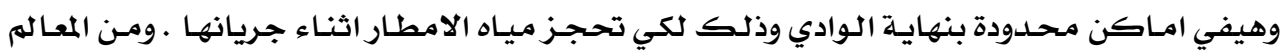

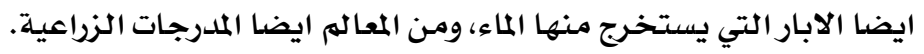




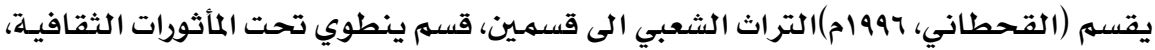

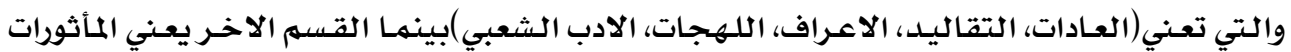

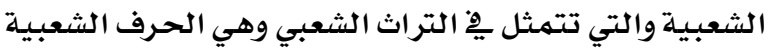

وقد عرف التراث الثعبي على انه ذلك" الجانب من ثقافـة الشعب الـذي حفظ شعوريا اولا

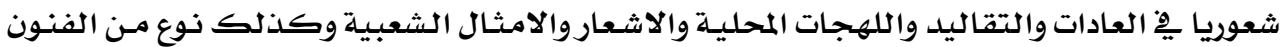

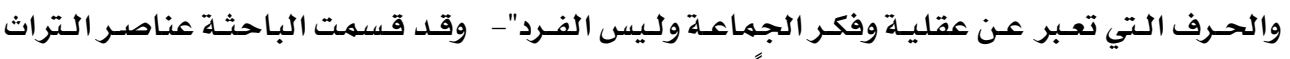

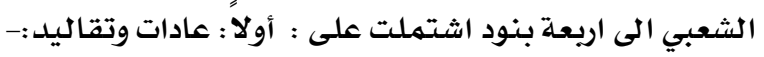

وهي الامور التي تتبعها القبائل والاهلي يِّ المنطقة والتي قد تكون متشابهة تبع للعرف مثل (العرس، المعونة، الاعياد،........)

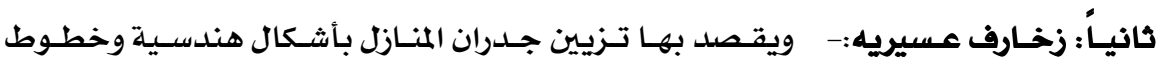

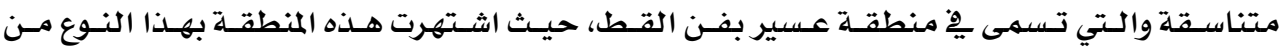
الفن الشعبي. المحور الثانى:ـ مرحلة محاولة التعبير الواقعي (من و الى السنة)

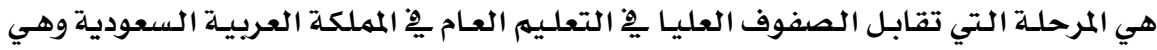

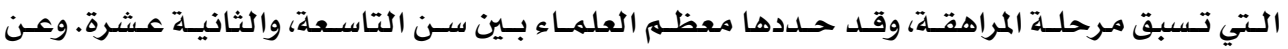

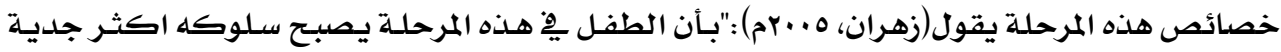

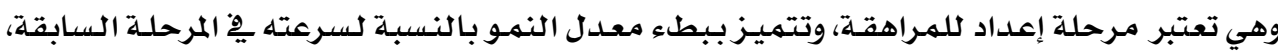

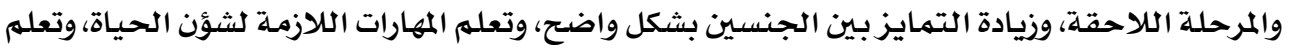

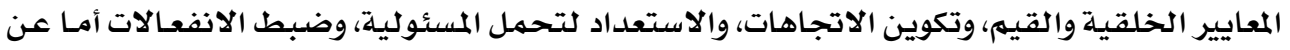

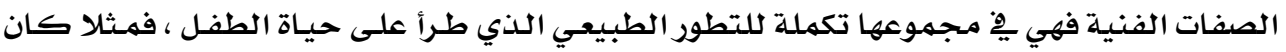

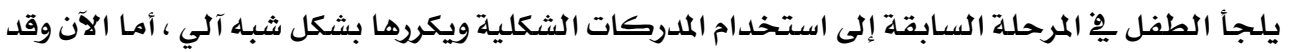

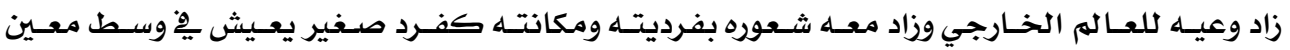

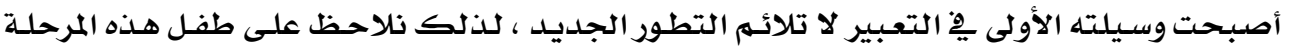

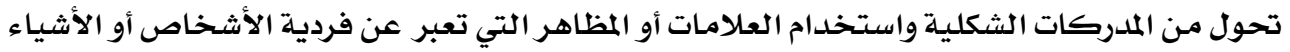

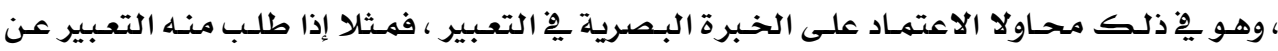

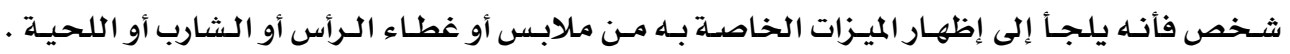

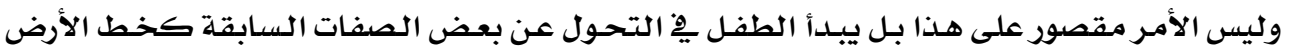

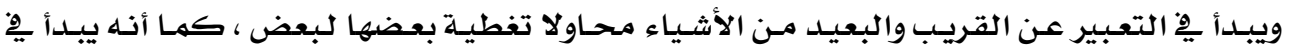

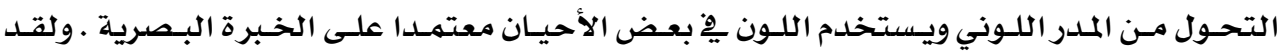




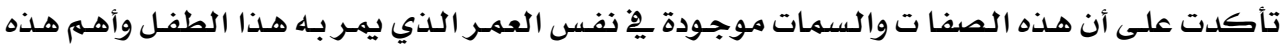

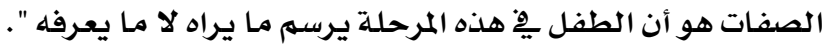

ومن أهم مظاهر النمو ِِِ هذه المرحلة:-

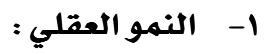

يقول(القحطاني عن زيدان، •991م) بأن الاطفال الذكور مِّ سن التاسعة ، والعاشرة يمتازون

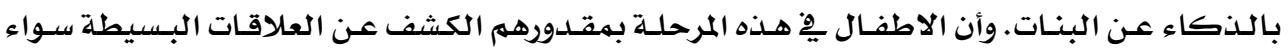

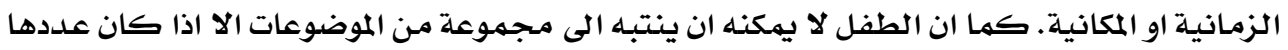

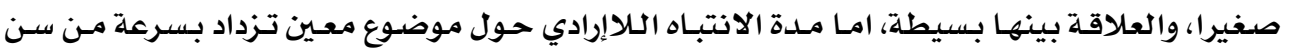

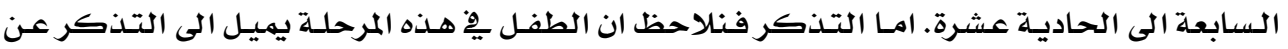

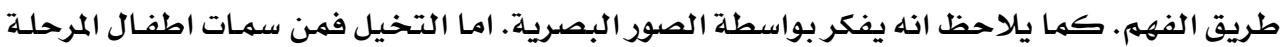

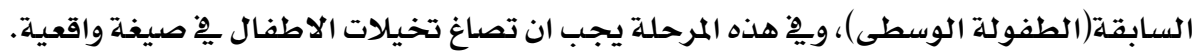

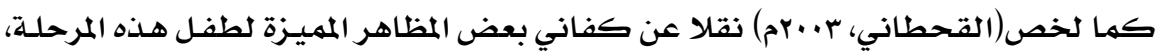

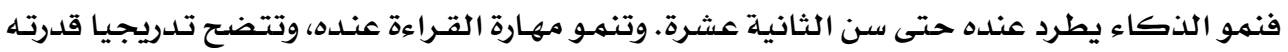

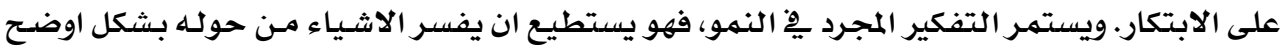

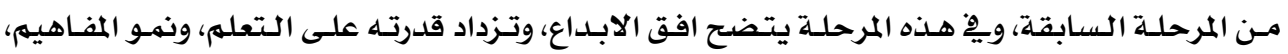
ويتحمس الطفل يْ هذه المرحلة لمعرفة الكثير عن البيئة.

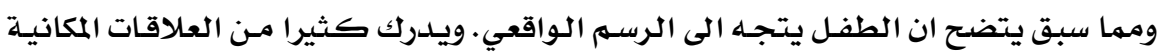

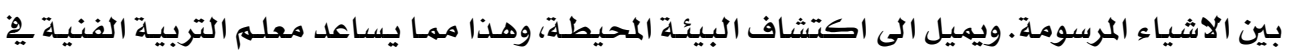

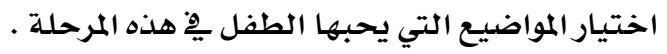

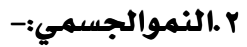

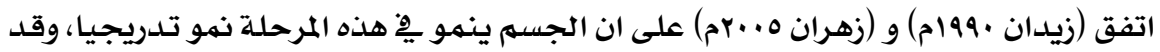

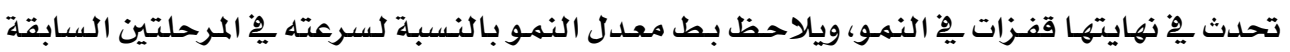

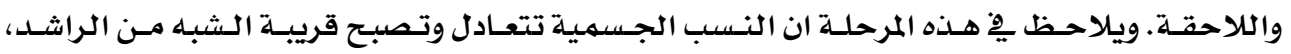

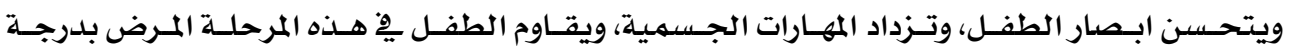

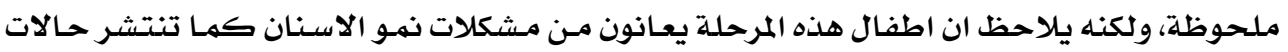

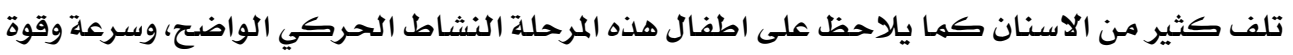

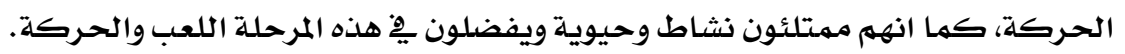

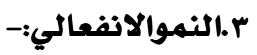

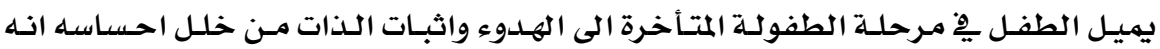

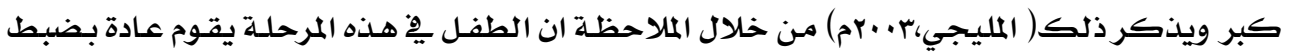




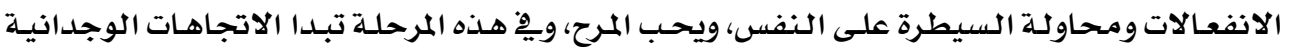

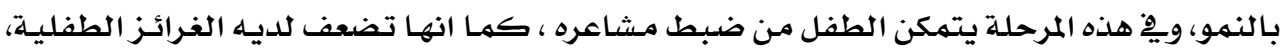

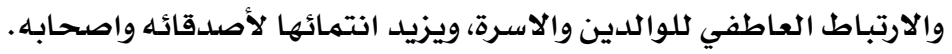

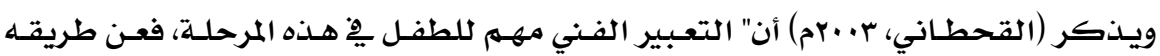

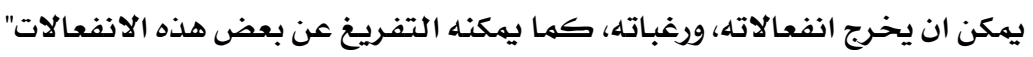

ع .النمو الاجتماعي:-

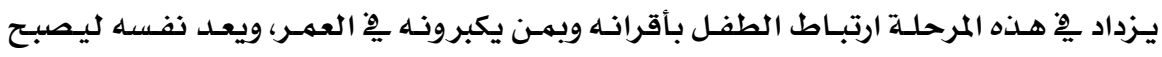

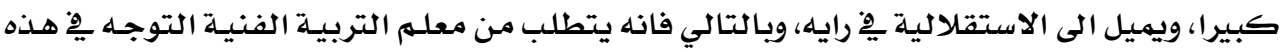

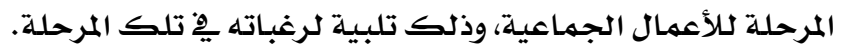

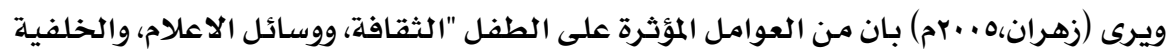

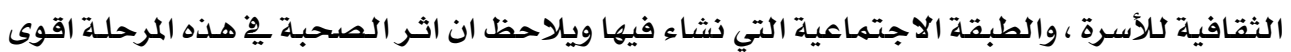

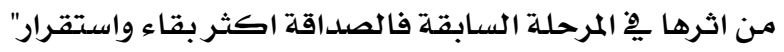

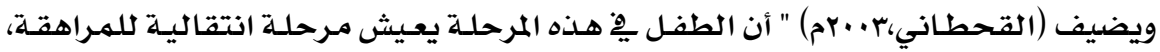

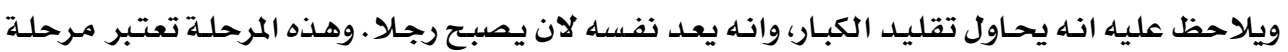

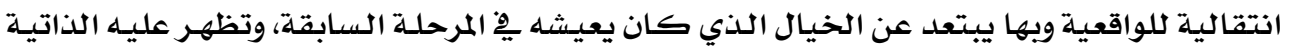

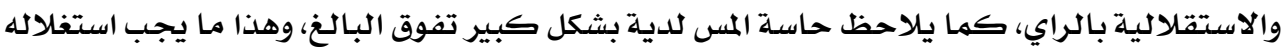

مِِّ دروس التربية الفنية". المحور الثالث:_رسوم الاطفال :-

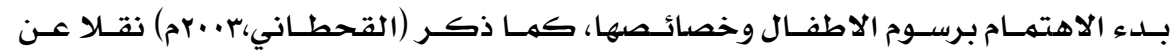

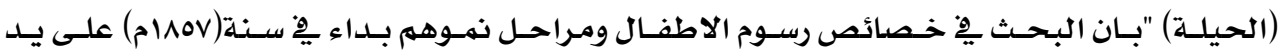

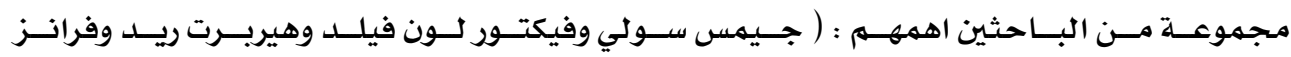

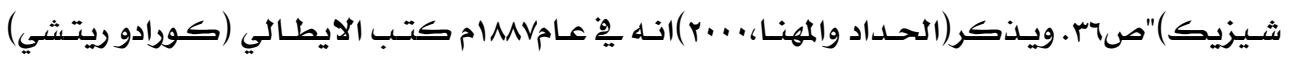

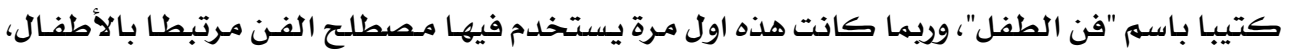

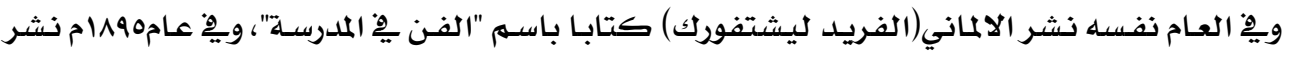

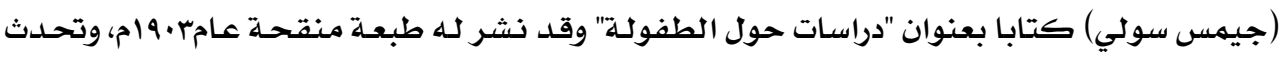

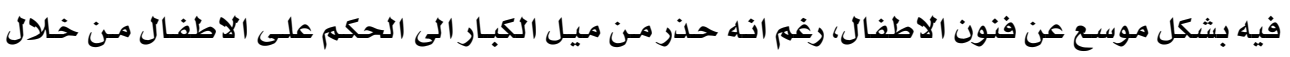
معاييرهم الخاصدة.

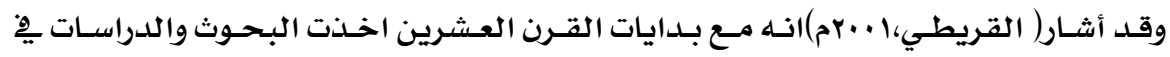

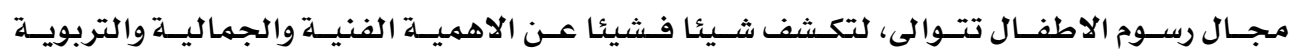

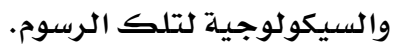


وتعتبر رسوم الاطفال وتعبيراته الفنية شكلا من اشكال فهمه تنفيس انفعالاته، فهي بهثابة

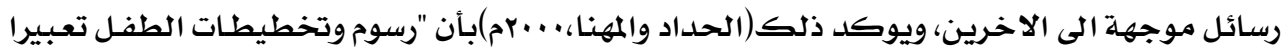

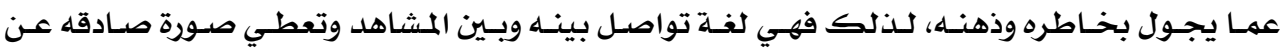

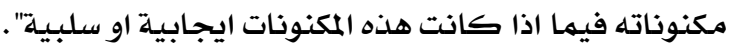

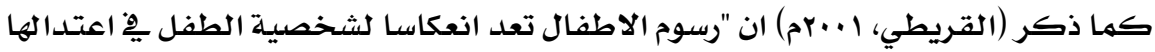

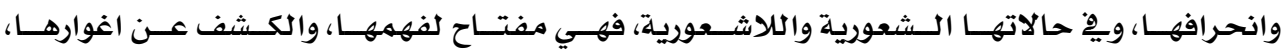

\section{وتقويهها وتوجيهها".}

وقد ذكرت (سناء علي \&991م) ان "رسوم الاطفال تعتبر لغة عالمية يتحدث بها جميع اطفال

$$
\text { العالم، ولذلك ان نعرف ان لهذه اللغة سمتان هما: }
$$

ا- سمـه عالمية تتعلق بالأسلوب الذي يتبعه الاطفال ِِ التعبير بالرسهم، الذي يتغير من مرحلة

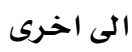

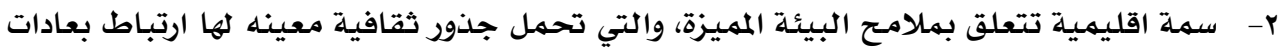

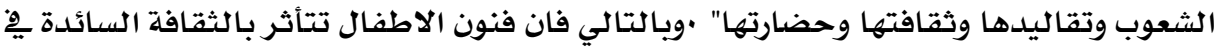

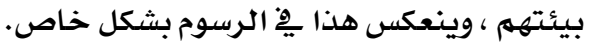

\section{مراحل تطور رسوم الاطفال مشتمل على تقسيم (فيكتور لو نفيلد )وتقسيم (هيربرت ريد )}

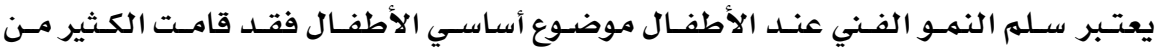

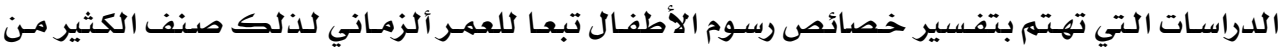

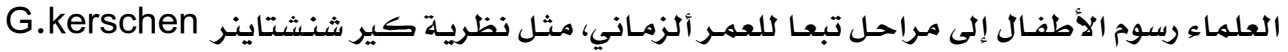

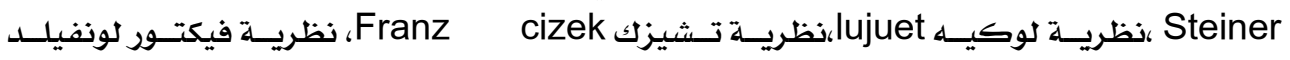
Lowenfie \&LBrittain وبريتن

تقسيم فيكتور لونفيلـ عـام (19VV) Lowenfied الأطفال .فتؤكد أن الأطفال يتغيرون لذلك يتغير فنهم ، وكان تقسيهها لارتقاء نشاط الرسهم عند الأطفال كهما يلي

$$
\begin{aligned}
& \text { : : } \\
& \text { : : من سنץ إلى ع سنوات. } \\
& \text { 1- مرحلة ما قبل التخطيط } \\
& \text { من سنع إلى V سنوات. } \\
& \text { r- مرحلة التخطيط }
\end{aligned}
$$

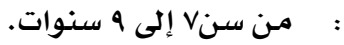

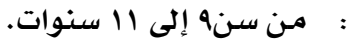

$$
\begin{aligned}
& \text { r- مرحلة تحضير المدرك الشكلي } \\
& \text { ع- مرحلة المدرك الشكلي } \\
& \text { : من سن|| إلى| سنوات. } \\
& \text { 0- مرحلة محاولة التعبير الواقعي } \\
& \text { ז- مرحلة التعبير الواقعي }
\end{aligned}
$$




$$
\text { تقسيم هيربرت ريد(9viم): }
$$

قام هيربرت ريد( •VV ام)بتقسيم مراحل تطور رسوم الاطفال وهي كالتالي : 1- مرحلة الشخبطة وتبدا من سنتين الى خمس سنوات ويبلـغ ذروته يِّ ثلاث سنوات

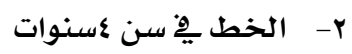

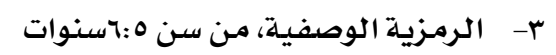

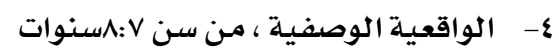

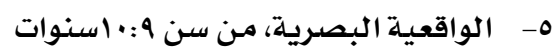

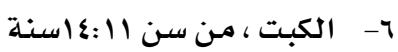

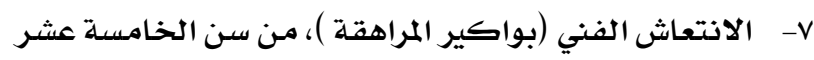

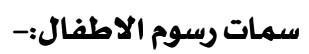

بناء على تقسيهم هيربرت ريـد وفكتور لونفيلد فأنها تنقسم هـذه المراحل داخليـا فيهـا بينها

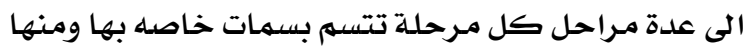

ا - مرحلة ما قبل التخطيط من سن الولادة الى سنتين ومن سماتها

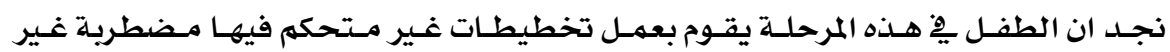
منتظمـة، تأتي نتيجة وضع القلهم على الورق ((تخطيطات عشوائية)) r - مرحلة التخطيط من سن Y:عوتنقسم الى اريعة اقسام لكل منه سمات يقوم فيها الطفل بعمل اريعة انواع من التخطيطات ومنها

$$
\begin{aligned}
& \text { أ- التخطيط غير المنتظم }
\end{aligned}
$$

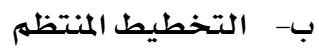

$$
\begin{aligned}
& \text { ت- التخطيط الدائري } \\
& \text { ث- الرموز المسمهاة }
\end{aligned}
$$

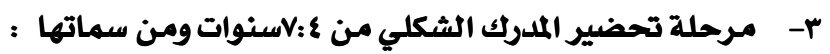

$$
\begin{aligned}
& \text { أ- رسوم محملة بالخبرة الواقعية }
\end{aligned}
$$

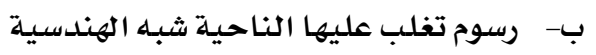

$$
\begin{aligned}
& \text { ت- تنوع ِِّ رسوم العنصر الواحد } \\
& \text { ث- اتجاه ذاتي نحو العلاقات المكانية لكلأشياء }
\end{aligned}
$$

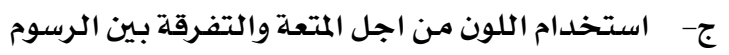




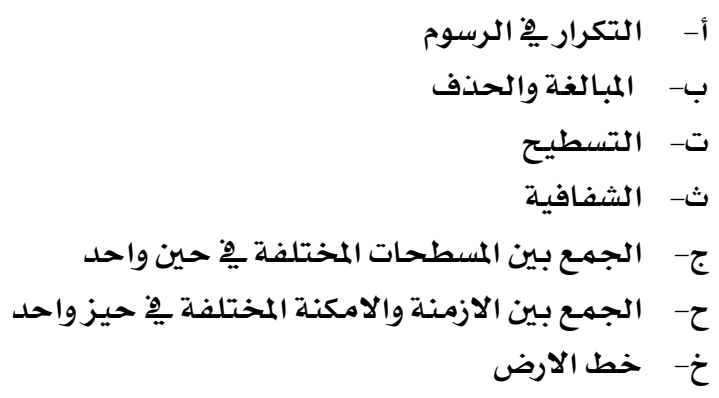

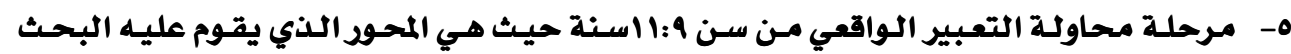
ومن سماتها

أ- التحول من الاتجاه الذاتي الى الاتجاه الموضوعي فالطفل ينتقل من الرسم من الذاكرة والخيال

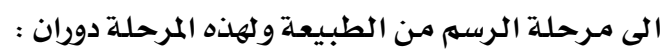

دور البعدين _ـ دور الثلاثة ابعاد فيحاول إظهار صفة الصـلابة، ويوجـه الانتبـاه نحـو الاشكال

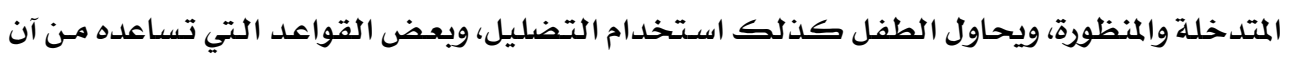

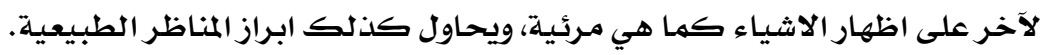
ب- التمسك بالعلاقات والمظاهر المميزة لكلأشياء ت- اختفاء بعض الاتجاهات السابقة

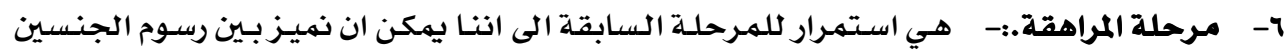
تمييزا واضحا

جـ - الفرق بين رسوم الذكور والاناث:- تؤكد دراسات علم نفس النمو ان الاطفال مـع قرب نهايـة

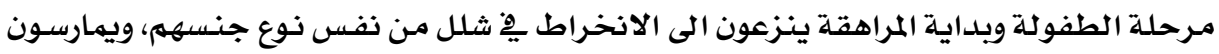

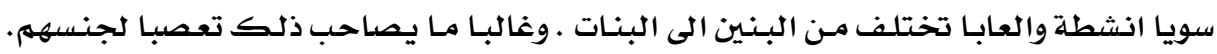

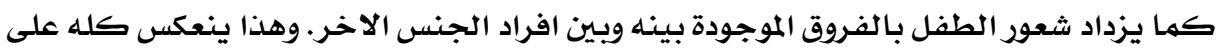

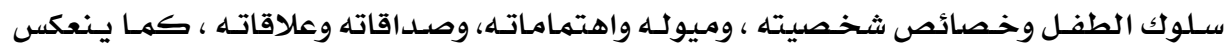

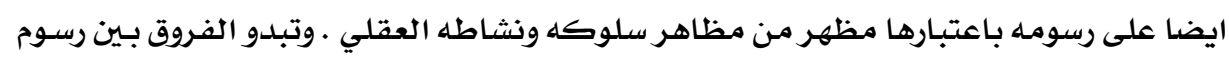

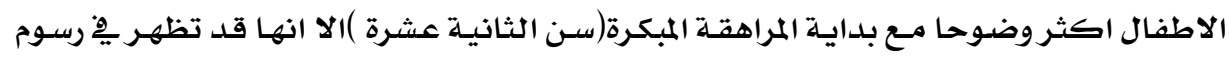

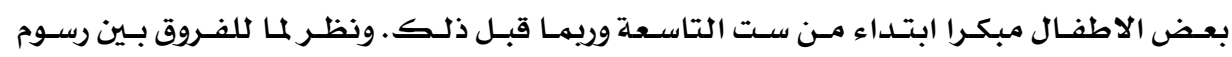

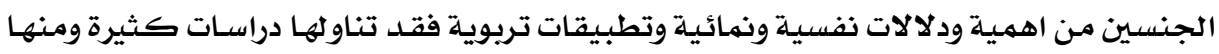

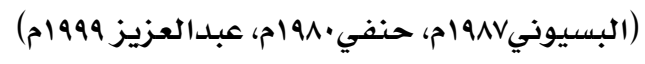


ويذلك يمكن تلخيص الفروق بين رسوم افراد الجنسين، وتصنيفها على النحو التالي :

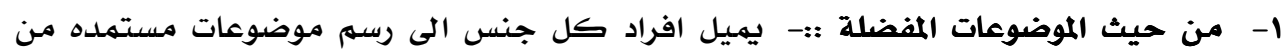

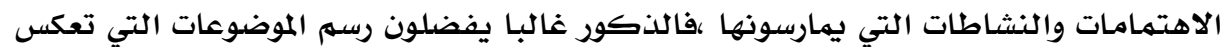

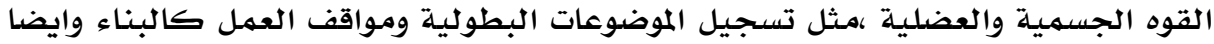

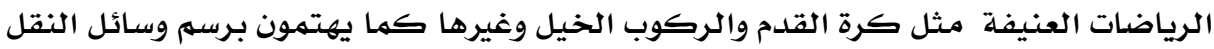

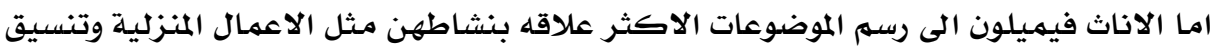

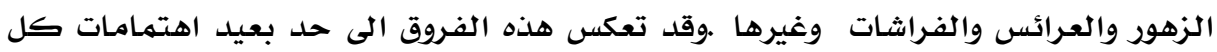

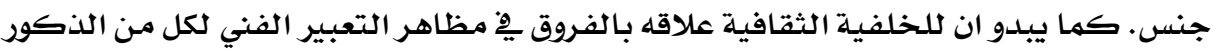

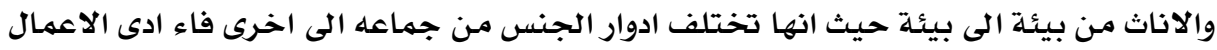

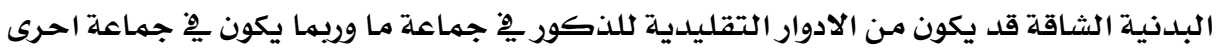
متعلق بالاناث.

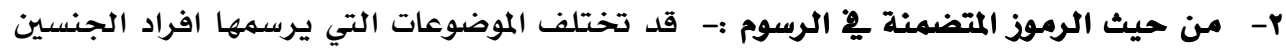

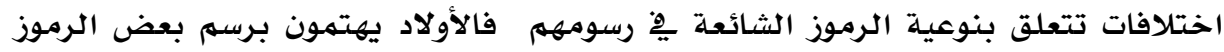

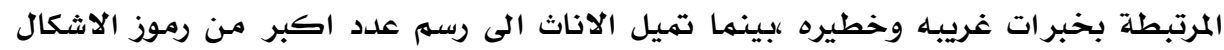

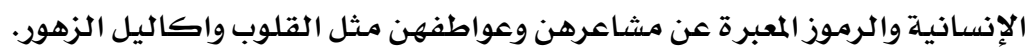

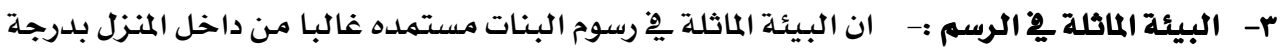

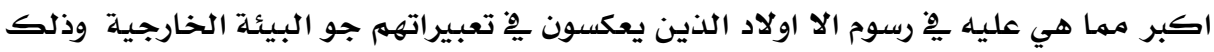

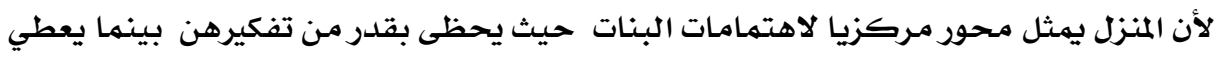

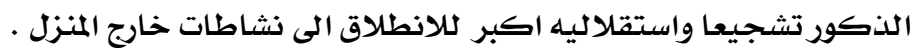
ع- من حيث الطابع العام للرسم : - رسوم البنين يغلب عليها الطابع التعبيري، والاهتمام

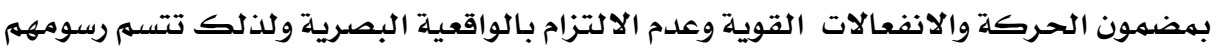

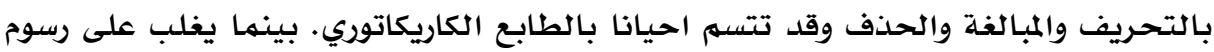

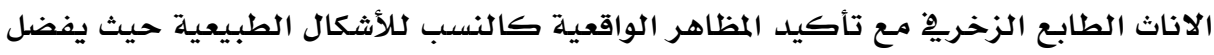

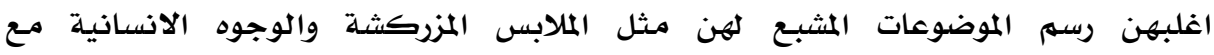

ه - من حيث تفاصيل الرسم : - يظهر اهتمام البنين بإبراز الصورة العامة لموضوع الرسم

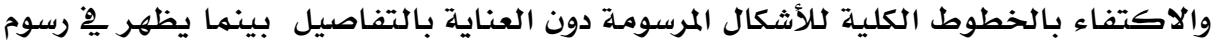

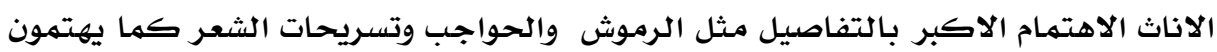

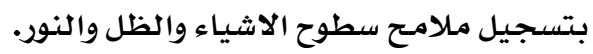
צ- من حيث خطوط الرسيم:- تتسهم خطوط الاثكال ِِّ رسوم الذكور بالقوة والصرامة وحدة

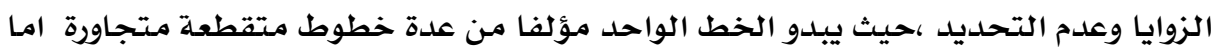

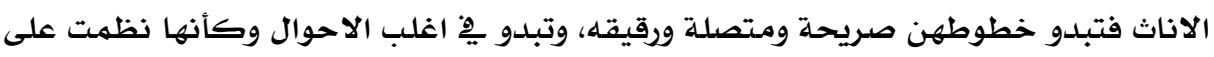


مهل كما يميلون الاناث الى استخدام الممحاة وذلك للحرص على اخراج الخطوط مضبوطة ونظيفة . مهل

V - من حيث الالوان المستخدمة ِِ الرسم :- يميل الذكور الى استخدام الألوان الممزوجة

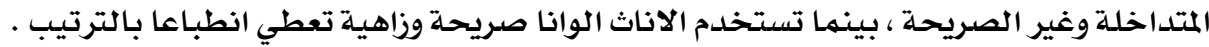

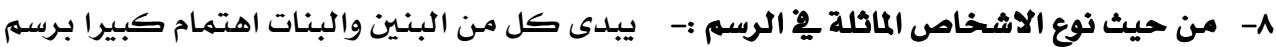

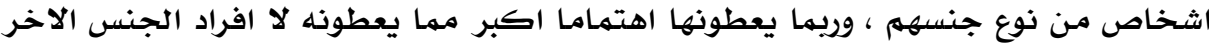

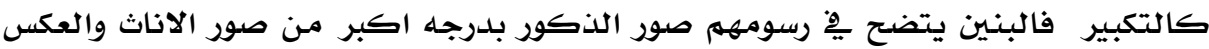
ايضا للبنات .

\section{البيئة والتعبير الفني:-}

ففي دراسـة (السيد،و991م) عن اختلاف البيئة أكدت أن لاختلاف البيئة بمكوناته الطبيعية

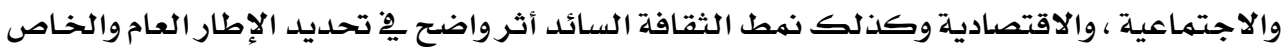

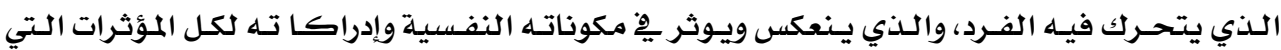

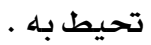

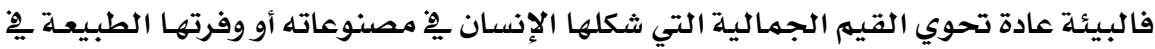

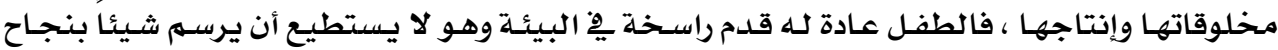

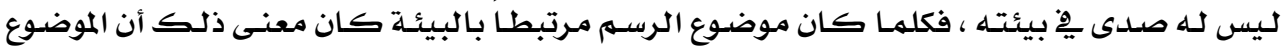

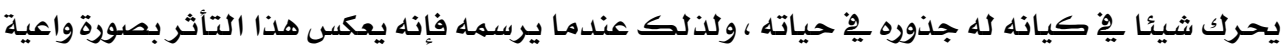

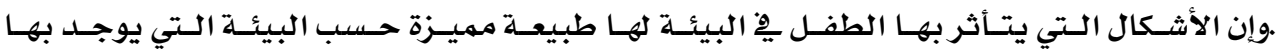

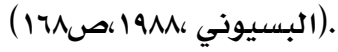

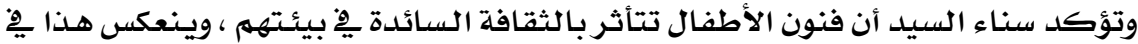

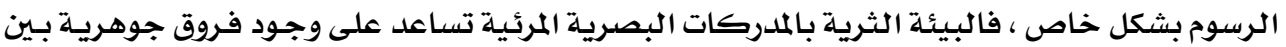

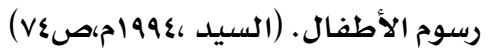

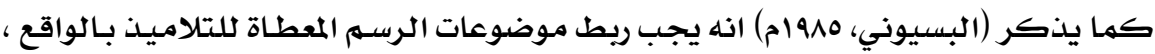

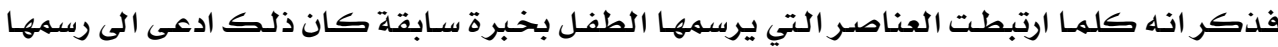

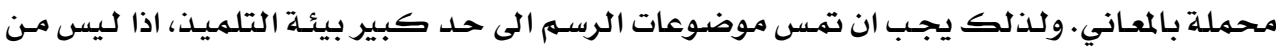

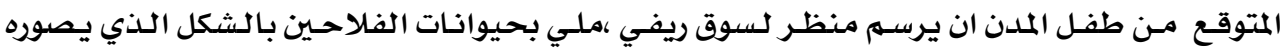

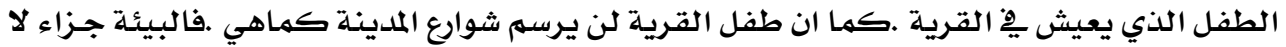

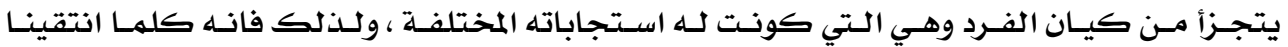

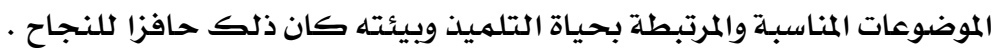
كما ذكر(السيد، عبدالرازق، بدون تاريخ) انه يمكن عن طريق الرسهم ايجاد العلاقة مـا بـين

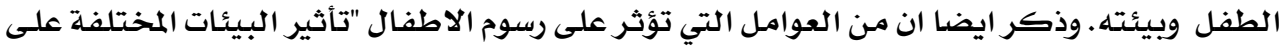




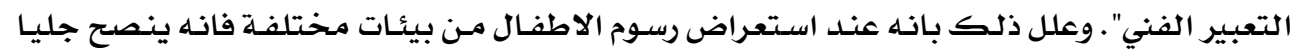

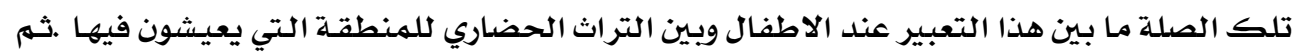

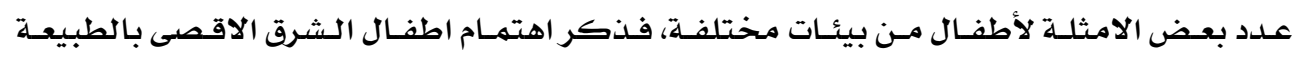

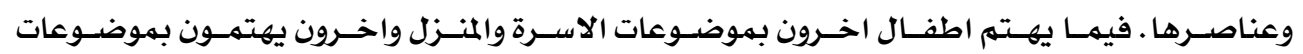
العمل والزراعة .

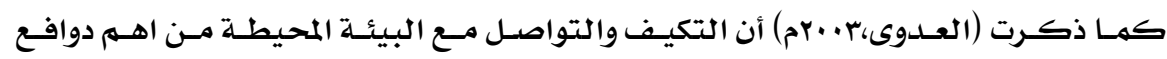

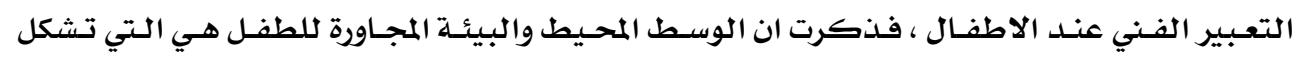

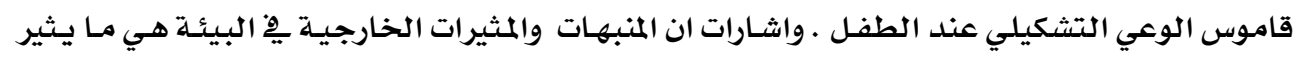

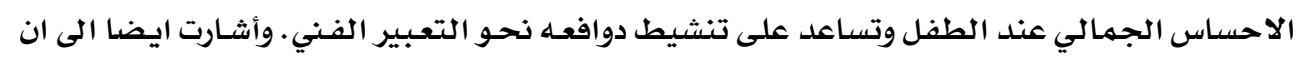

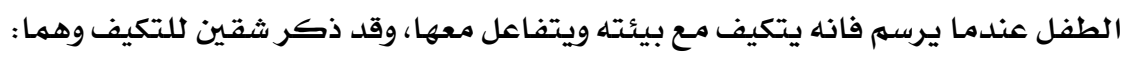

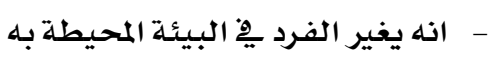
- - مِِ نفس الوقت يتغير الفرد بتأثير البيئة.

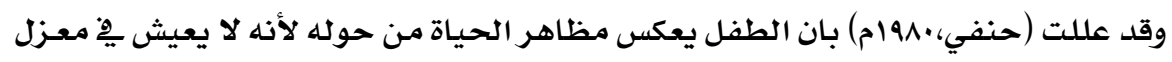

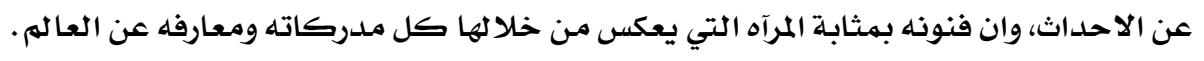

\section{الدراسات السابقة}

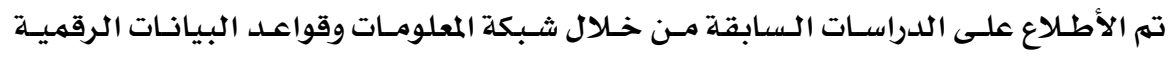

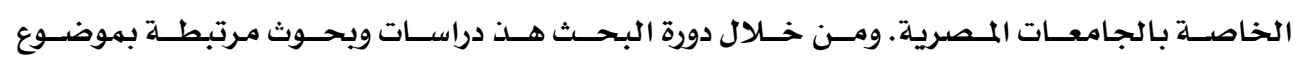

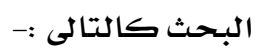

وقد حظي مجال التربية الفنية باهتمام الباحثين والمفكرين التربويين، فقد وجدات الباحثة

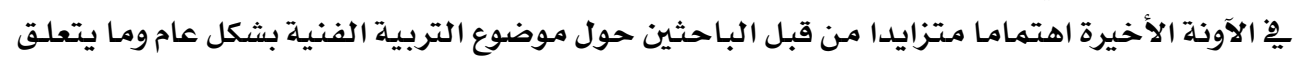

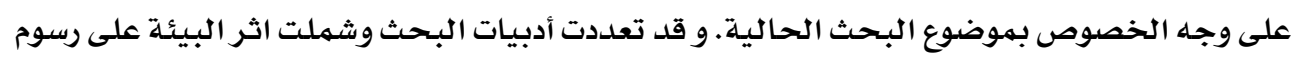

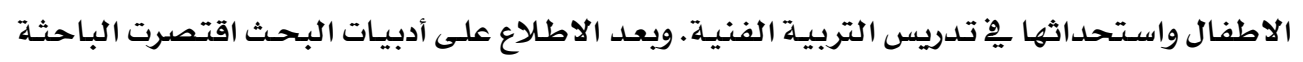

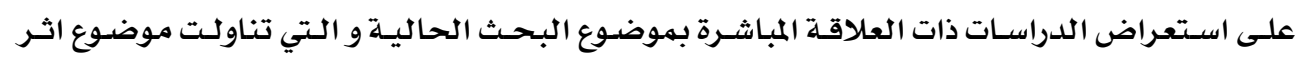

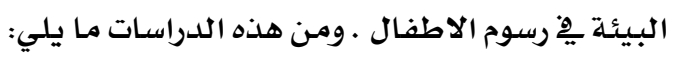

اـ حمدي عبداكريم، (1998م) مشروعات تجميل وتحسين البيئة (القرى السياحية بالملد الجديلدة).

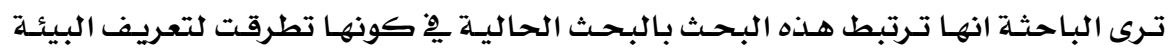

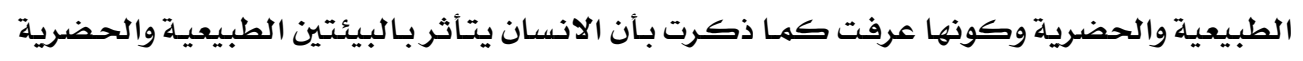

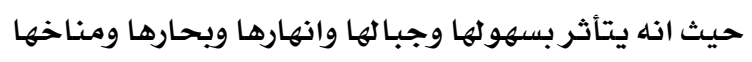

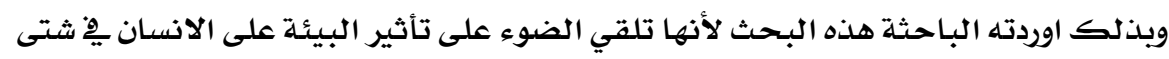

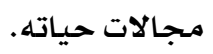


وقد هدفت هذه البحث الى معرفة الاختلافات الفردية ِِِ رسوم الطفل ِِّ السعودية تبعـا لا

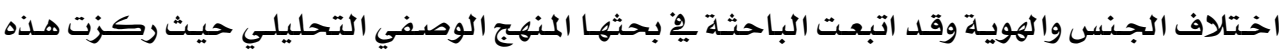

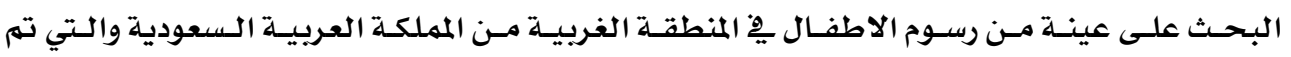

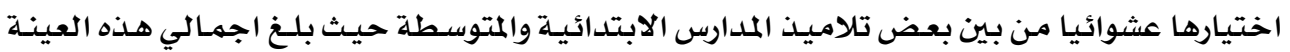
(1749 ) من الذكوروارالاناث وقد توصلت الباحثة الى النتائج التالية :

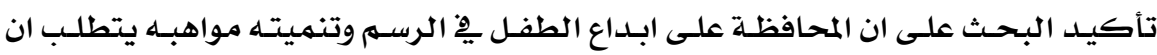

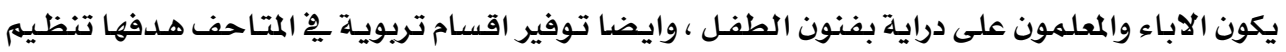

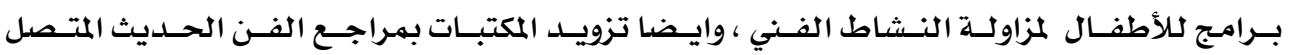
بفن الطفل

\section{rــ محمد حسين الضويحي "نظريات رسوم الأطفال: النشأة والتطور"}

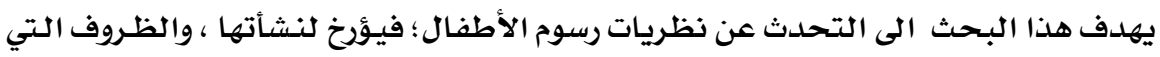

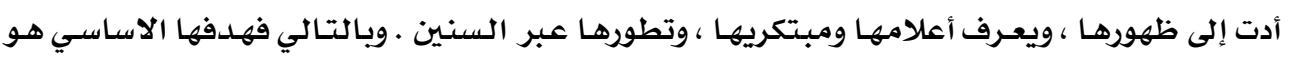

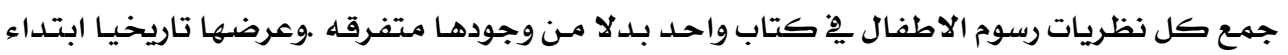

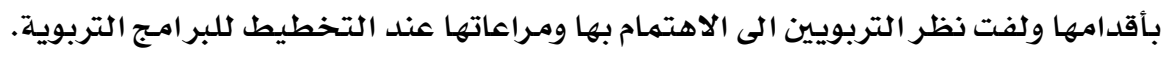

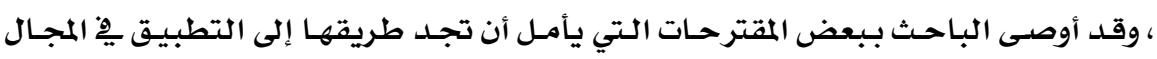

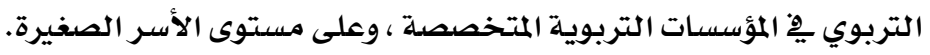

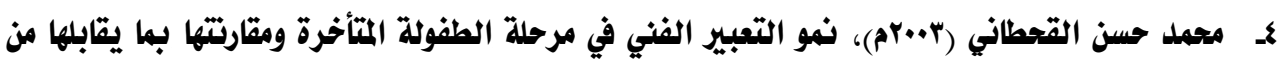
مراحل تقسييم (فيكتور لونفيلد وهيربرت التون ريلد).

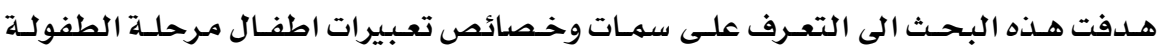

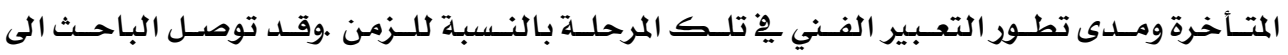

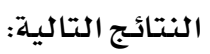

لا يهكن تحديد مراحل نمو التعبير الفني بفترات قصيرة. كما إن نتائج هذا البحث تختلف

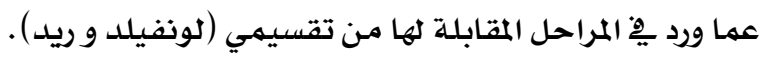

هناك بعض خصائص تعبيرات الأطفال التي مـازالت ملاحظلة على تعبيرات أطفال مـرحلـة

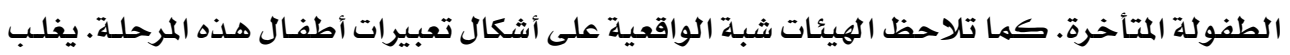

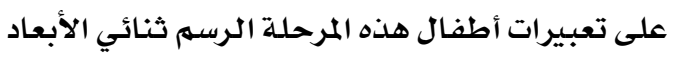

هـ فاطمه حمد الحربي، (V+•rم) (نوع وكم الملدركات البصرية في رسوم طفل ما قبل الملدرسة )

هدفت هذه البحث الى التعرف على مدىى اختلاف نوع وكم المدرركات البصرية لدى الطفل

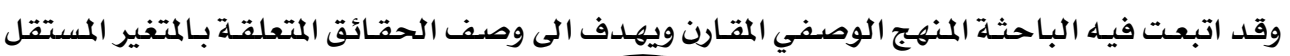

\section{$\bullet \wedge$.}




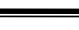
مجلة بحوث التربية النوعية - علد اع - ميناير r r

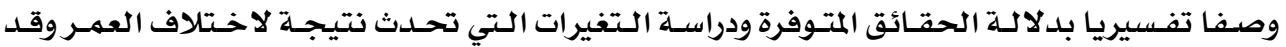
توصلت الباحثة الى النتائج التالية .

أن سلوك الطفل يتشكل وفقا للبيئـة التي نشأ فيها وتفاعل معها فينعكس ذلك على ثقافة وأحاسيسـه وإعماله .

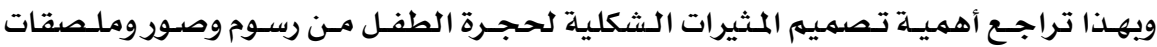

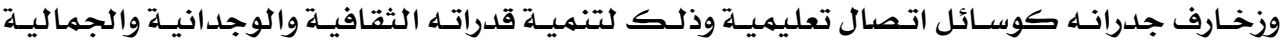

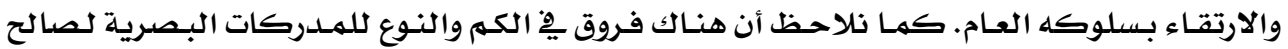
عينة الاطفال التمهيدي المتقدم والمتتأخر.

كمــا اوصـت الباحثـة بزيـادة الأبحــاث الـتي تتنــاول الإدراك البـهري لأهميـة المـدركات البصريـة ِِ التعرف على البيئة المحيطة بـالطفل.

والبحث يِّ المجالات الأخرى الفنية يِ فنون الطفل كالأثغال الفنيـة - الصلصال وغيرهـا

$$
\text { من مـجالات التعبير الفني وعلاقتها بـالإدراك البصري. }
$$

أن تعـي الأسـرة بأهميـة تشجيـع الطفل على التعبير الفـني وتنميـة قدرات الطفل الجسسمية والعقلية والنفسيـة.

كمـا اوصست البـاحثة بـالاهتهـام برسـوم الطفـل والـتي يعبر بهـا عـن نفسـه وعمـا حولـه مـن أحداث هـامـة بـالنسبـة له بصورة تلقائيـة مها يزيد من توازنه النفس والاجتهـاعي. كما يجب على الأسـرة والمربون تفسير تلك المدركات البـصرية التتي يرسهها الطفل لبنـاء تواصل جيد مـع الطفل و فهم طبيعة شخصيته.

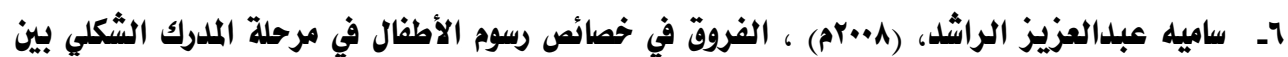

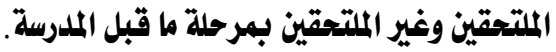

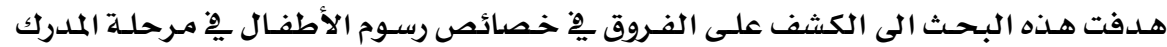
الشكلي بين الملتحقين وغير الملتحقين بهـرحلة مـا قبل المدرسلة. والتعرف عن مدى تأثير الالتحاق بهـرحلة مـا قبـل المدرسـة على خصـائص رسـوم الأطفـال ِِ مـرحلة المدرك الشكلي. وقد توصلت الباحثة الى النتائج التالية: لاحظت ظهور فـروق يِ خـصائص رسـوم الأطفـال يْ مـرحلـة الملدرك الشكلي بـين الملتحقين وغير الملـتحقين بهرحلـة مـا قبـل المدرسـة لـصالح الأطفـال الملتحقين ،وكـان يظهر هـذا الفـرق بشكل

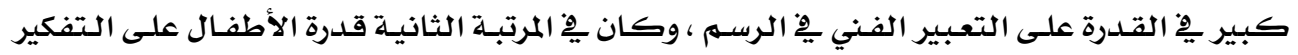
الابتكاري من خلال الرسوم وقد كانت رسوم الأطفال الملتحقين أكثر ابتكارا من رسوم الأطفال الغير

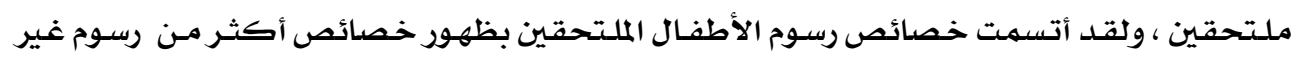
الملتحقين وإن كان هذا أقل المحاور ظهورا للفرق إلا أنه كان فرقا يتميز بـه رسوم الأطفـال الملتحقين عن غير الملتحقين. 
كما أوصـت الباحثثة ،بتوعيـة الأسـرة عن طريق وسـائل الإعلام عن مـدى أهميـة مرحلـة مـا

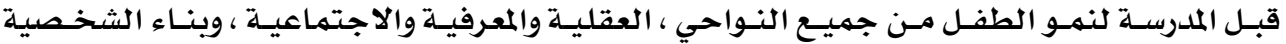
المتكاملة للطفل. ضرورة الاهتمام بمرحلة ما قبل المدرسـة وجعلها ضمن السلهم الإلزامي للتعليم. ضرورة التواصل بين الأسرة والمدرسة بما يعود بالنفع على الأطفال.

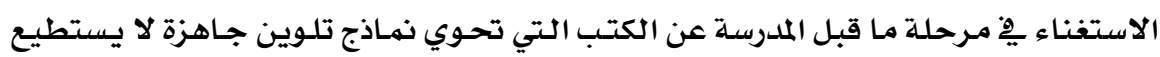

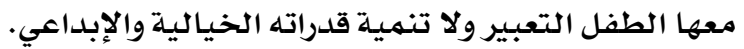

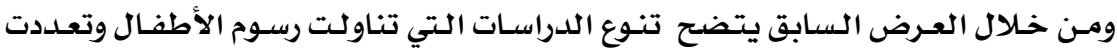

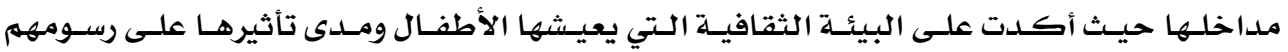

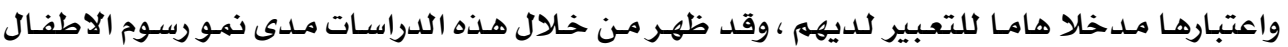
وتطورها تبعا لمراحل النمو المختلفة وكيف تتنوع هذه الرسوم وتختلف مـن حيث البيئسة وبـين الفئـات

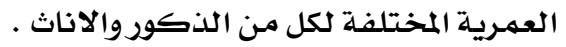

\section{إجراءات البحث :- هنهج البحث:-}

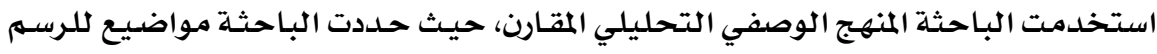

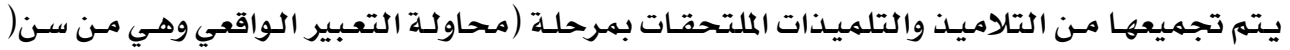

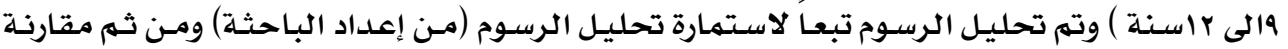

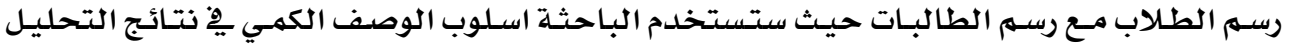

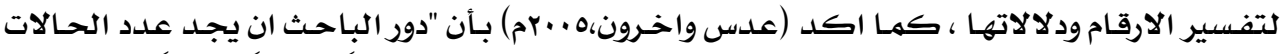

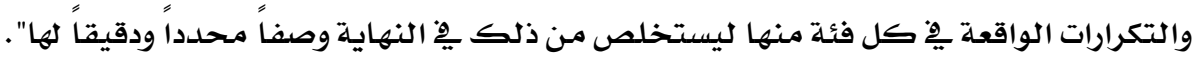

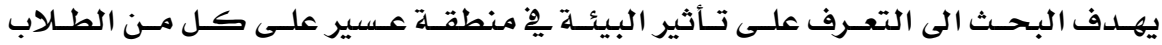

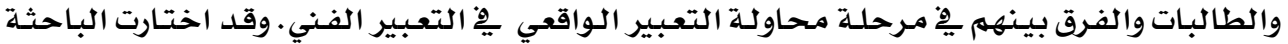

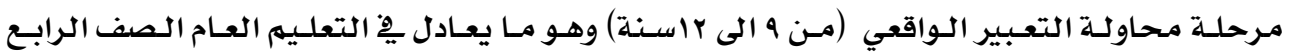

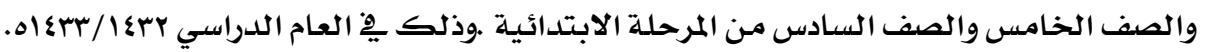

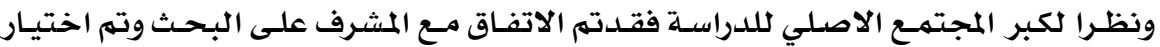

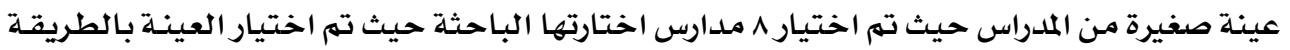

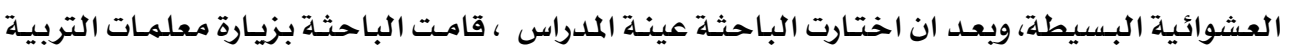

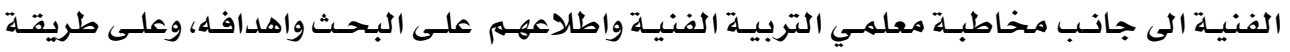

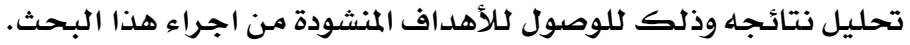




\section{جمه العهينة :}

قامت الباحثة بجمـع الرسومات من عينة المدارس التي وقع عليها الاختيار مِِّ نهايـة الفصل

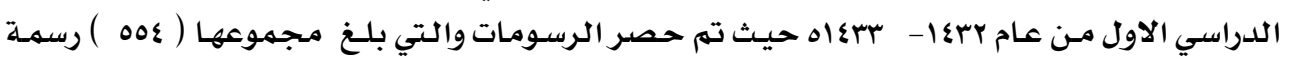

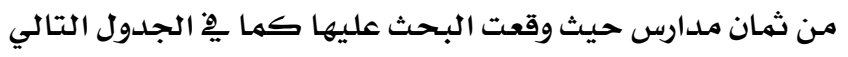

جدول رقم (1)

\begin{tabular}{|c|c|c|}
\hline \multicolumn{2}{|c|}{ علد الرسومات } & \multirow[b]{2}{*}{ الصف } \\
\hline & الذكور & \\
\hline $1 \cdots$ & 9. & الرابع \\
\hline 99 & A. & الخامس \\
\hline$\wedge \wedge$ & $9 V$ & السادس \\
\hline YAY & YYY & المجموع \\
\hline
\end{tabular}

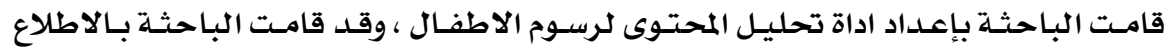

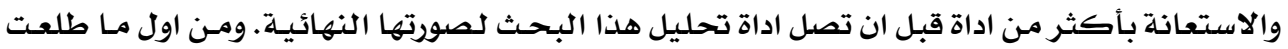

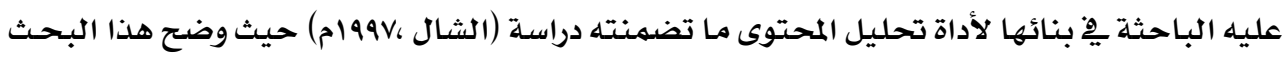

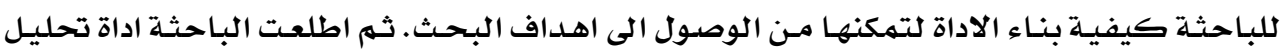

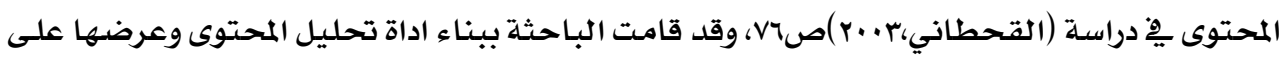

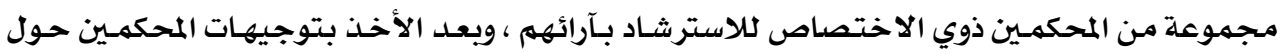

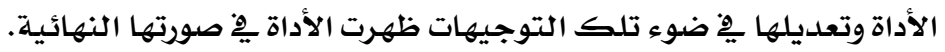

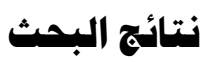

السؤال الاول : ما تأثير عناصر بيئة منطقة عسير والتي تظهر في تعبيرات الاطفال في مرحلة محاولة التعبير الواقعي؟ تأتير عاصي

يتحقق الهدف الاول ِِّ هذا البحث من خلال الاجابة على السؤال الاول، فقد قامت الباحثة

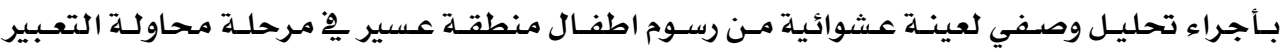

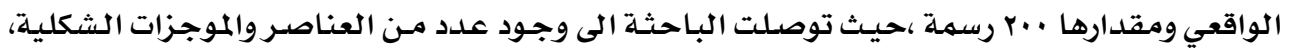

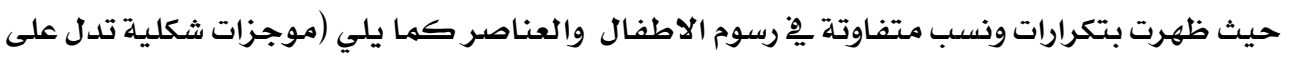

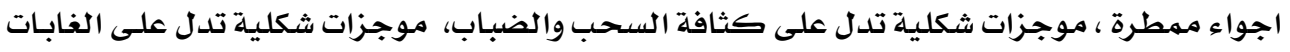

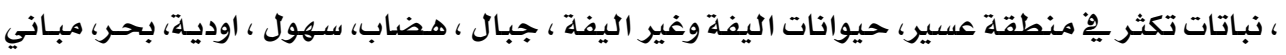

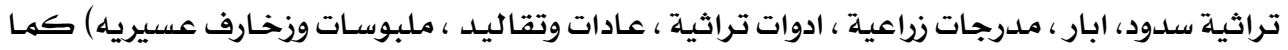

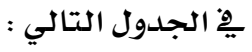




\section{جدول رقم(ץ)}

نسب التكرارات الواردة لدى التلاميذ ِِّ رسم الموجزات الشكلية لبيئة منطقة عسير

\begin{tabular}{|c|c|c|c|}
\hline 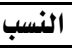 & التكرارات & الفئات & 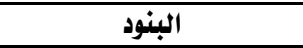 \\
\hline $7 r, 0$ & IrY & موجزات شكلية تدل على اجواء مهطرة & \multirow{2}{*}{ مناخ } \\
\hline rr & 187 & موجزات شكلية تدل على كثافة السحب والضباب & \\
\hline$r \xi, 0$ & $\$ 9$ & موجزات شكلية تدل على الفابات & \multirow{2}{*}{ 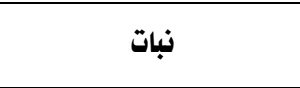 } \\
\hline 7,0 & ir & نباتات تكثر في منطقة عسير & \\
\hline$\xi$ & $\wedge$ & حيوانات اليفة & \multirow{2}{*}{ 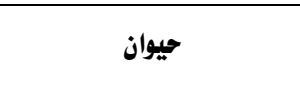 } \\
\hline 1,0 & $M$ & حيوانات غير اليفة & \\
\hline 91,0 & MAT & جبال & \multirow{5}{*}{ تضاريس } \\
\hline$\wedge$ & 17 & هضاب & \\
\hline$r$ & 7 & سهول & \\
\hline 01 & $1 \cdot Y$ & اودية & \\
\hline 9,0 & 19 & بحر & \\
\hline$\wedge 1,0$ & 174 & مباني تراثية & \multirow{4}{*}{ معالم عسيريه من صنع الانسان } \\
\hline$r$ & $\xi$ & سلدود & \\
\hline 11 & rr & آبار & \\
\hline 0 & 1. & ملدرجات زراعية & \\
\hline ir & $Y \xi$ & ادوات تراثية & \multirow{4}{*}{ تراث شعبي } \\
\hline$r, 0$ & $\checkmark$ & عادات وتقاليد & \\
\hline 0,0 & 11 & ملبوسات عسيريه & \\
\hline 9 & 11 & زخارف عسيريه & \\
\hline
\end{tabular}

السؤال الثاني :ما ملى تأثير بيئة منطقة عسير على تعبيرات الاطفال الفنية في مرحلة محاولة التعبير الواقعي؟ رسارئ

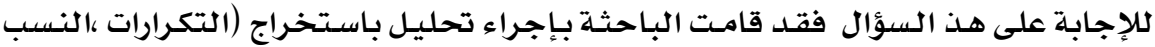

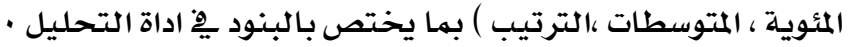

$$
\text { جدول رقم (r) }
$$

التكرارات والنسب المئوية والمتوسطات والترتيب لبنود التأثير

\begin{tabular}{|c|c|c|c|c|c|c|c|c|c|}
\hline \multirow[b]{2}{*}{ الترتيب } & \multicolumn{2}{|c|}{ المتوسط } & \multicolumn{2}{|c|}{ الصف السادس } & \multicolumn{2}{|c|}{ الصف الخامس } & \multicolumn{2}{|c|}{ الصف الرابع } & \multirow[b]{2}{*}{ البنود } \\
\hline & $\%$ & ك & $\%$ & التكرارات & $\%$ & التكرارات & $\%$ & التكرارات متوسط & \\
\hline 1 & $V_{r}, q$ & $1+7,0$ & $V \xi, r$ & IrV & $V \xi, \Lambda$ & Irs & Vr,O & IrA & مناخ \\
\hline$\varepsilon$ & rI & $71, r$ & $r \xi, 1$ & $\xi \xi, 0$ & rr, & $\xi \cdot, 0$ & $17, r$ & rI & نبات \\
\hline 7 & $I I, r$ & $r q, v$ & $1 \cdot, 1$ & r. & $1 r, \Lambda$ & rr & $9, Y$ & 11,0 & حيوان \\
\hline$r$ & $r r, 1$ & 71 & $r \cdot, r$ & $\Delta 0, \Lambda$ & $r q, 7$ & 70,7 & rr, & 71,7 & تضاريس \\
\hline$r$ & $r \wedge, 1$ & 01,9 & ro, 9 & $\{\wedge$ & $r \cdot, r$ & $\Delta\}, r$ & rA & or,r & من صنالم عسيريه الانسان \\
\hline 0 & $\mid \varepsilon, 1$ & ro, 1 & IV, T & $r Y, O$ & 10,9 & $r \wedge, 0$ & $\wedge, \vee$ & 17,0 & تراث شُعبي \\
\hline \multicolumn{3}{|c|}{$\% r \cdot, r$} & \multicolumn{2}{|c|}{$\% r \cdot, 0$} & \multicolumn{2}{|c|}{$\%$ rr,O } & \multicolumn{2}{|c|}{$\% Y Y, 90$} & المتوسط \\
\hline
\end{tabular}




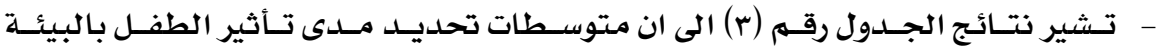

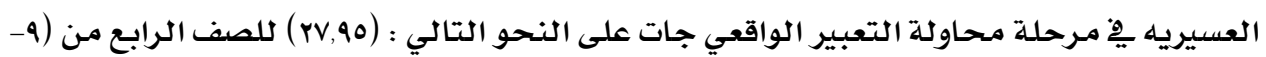

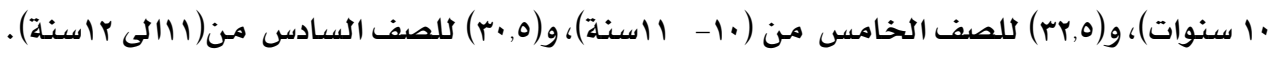

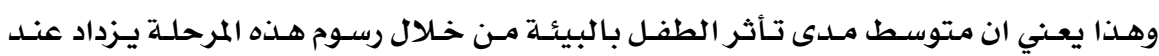

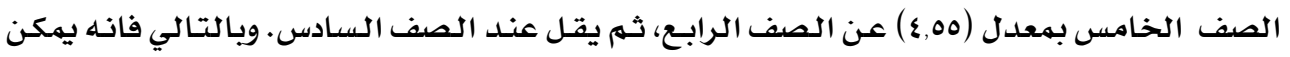

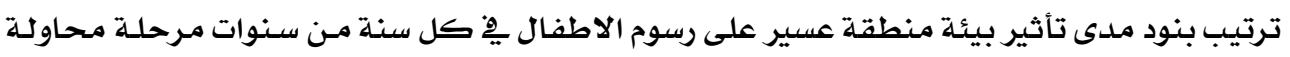

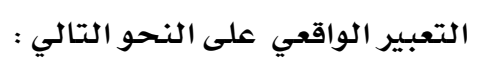
• الصف الرابع من (9 - • اسنوات) :"مناخ، تضاريس، معالم عسيريه ، نبات ،تراث شعبي".

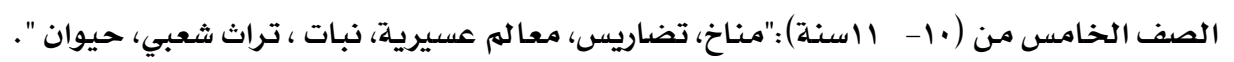

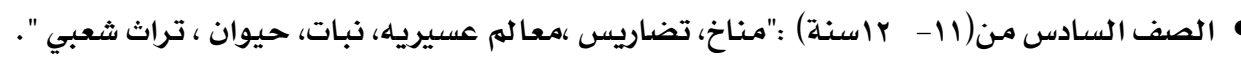
بالتالي فان متوسطات تأثير البيئة على رسوم الاطفـال ِِّ مرحلـة محاولـة التعبير الواقعي

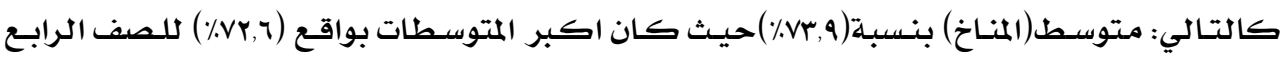

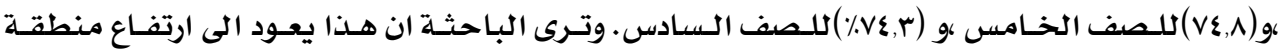
عسير وبرودة الطقس.

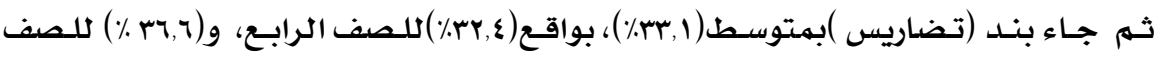

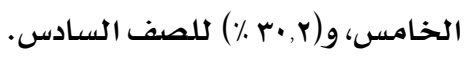

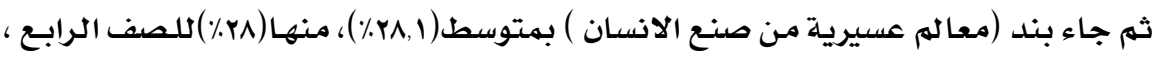

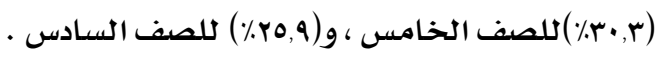

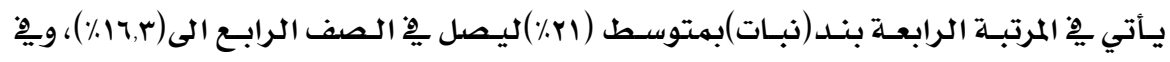

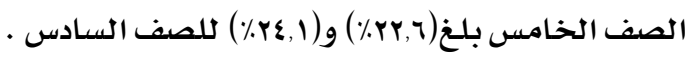

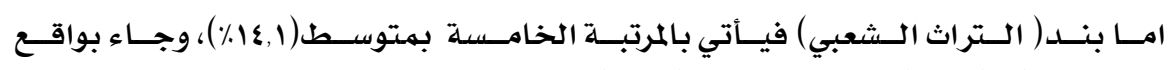

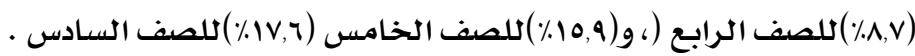

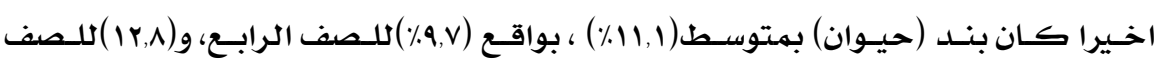

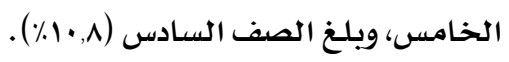
السؤال الثالث: ما أبرز الفروق بين فئات عناصر بيئة منطقة عسير في رسوم الاطفال الذكور والاناث في سنوات

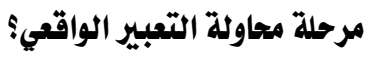

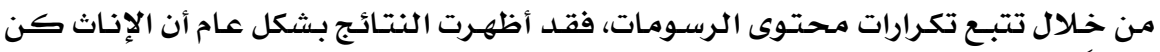

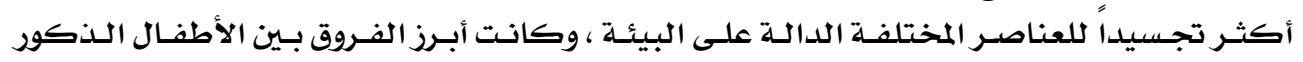
والإناث كالتالي: 


\section{جدول رقم ( ع )}

تحليل محتوى رسوم الاطفال الذكوروالاناث ِِ2 منطقة عسير لمرحلة محاولة التعبير الواقعي

\begin{tabular}{|c|c|c|c|c|c|}
\hline ملاحظات & لا يوجد & $\cdots$ & الجنس & الفئات & البنود \\
\hline & & $\sqrt{ }$ & ذكور & \multirow{2}{*}{ موجزات شكليه تل على اجواء } & \multirow{2}{*}{ المناخ } \\
\hline & & $\checkmark$ & أناث & & \\
\hline & & $\sqrt{ }$ & ذكور & \multirow{2}{*}{ موجزات شكليه تدل على جبال ـ - هضاب ـ اوديل - سهول } & \multirow[b]{2}{*}{ التضاريس } \\
\hline & & $\sqrt{ }$ & أناث & & \\
\hline & & $\sqrt{ }$ & ذكور & \multirow{2}{*}{ موجز شكلي يلدل على الفابات } & \multirow{2}{*}{ النباتات } \\
\hline & & $\checkmark$ & أناث & & \\
\hline & & $\sqrt{ }$ & ذكور & \multirow{2}{*}{ مباني تراثيه ـ أبارـ مزارع } & \multirow{2}{*}{ معالم من صنع } \\
\hline & & $\sqrt{ }$ & أناث & & \\
\hline & & $\checkmark$ & زكور & \multirow{2}{*}{ ادوات تراثيه ـ عادات وتقاليد } & \multirow{2}{*}{ تراث شعبي } \\
\hline & & $\checkmark$ & 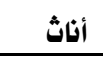 & & \\
\hline
\end{tabular}

أولاً: الرسومات التي تكررت لدى الإناث أكثر منها للدى الذكور

\section{• الفروق مِّ رسم المناخ (موجزات شكليه تدل على اجواء ممطره وكثافة السحب والضباب)}

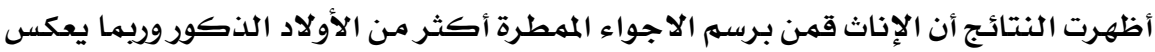

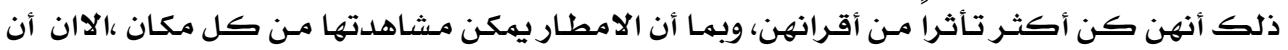

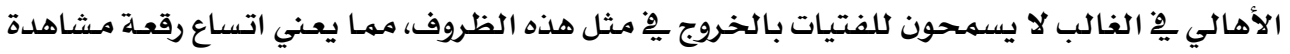

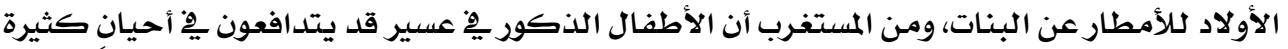

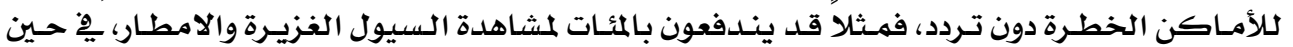

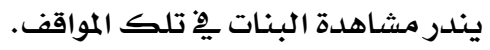




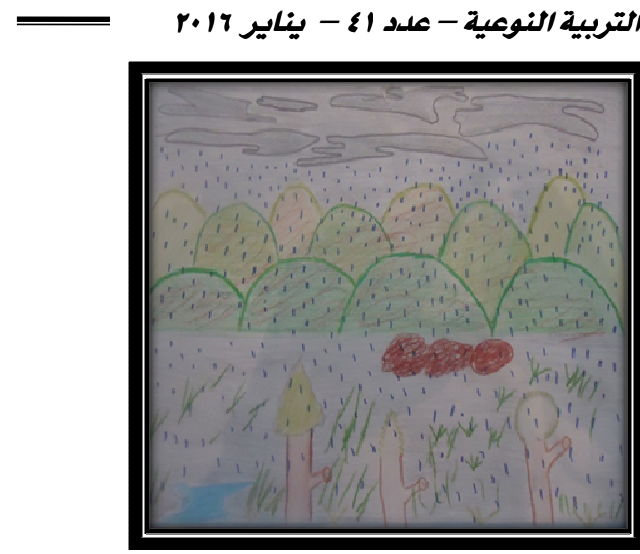

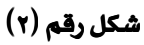

مهند ظافر

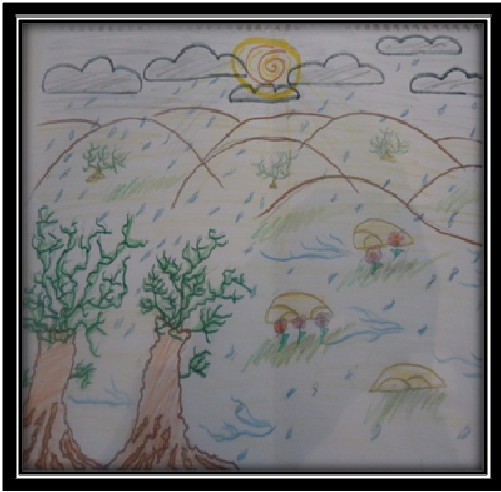

شكل رقم (1) منال عبدالله

$$
\text { الفروق يِّ رسم التراث الشعبي (ادوات تراثيه - عادات وتقاليد وملبوسات وزخارف عسيريه) }
$$

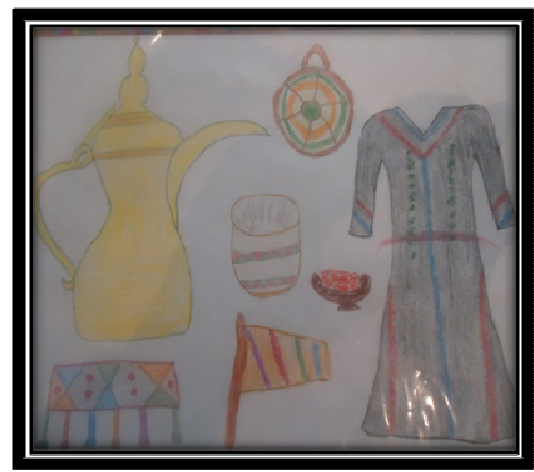

شكل رقم(ع)

يزن محمد

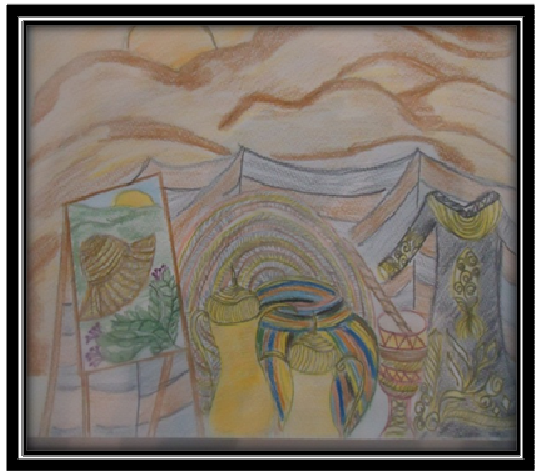

شكل رقم(r)

يلاحظ ان نسبة البنات الكلاتي رسمن بيوتاً وملابس وزخارف عسيريه فاقت نسب الأولاد وقد الداء

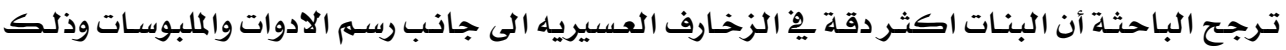

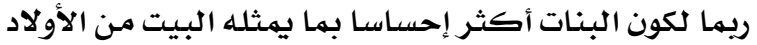

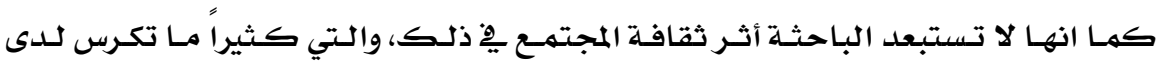
الطفل الذكر مفاهيم معينة تجعله ينفر من بعض الميزات التي يريطها الكبـار بالبنـات، ومنهـا الزينـة

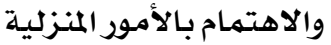




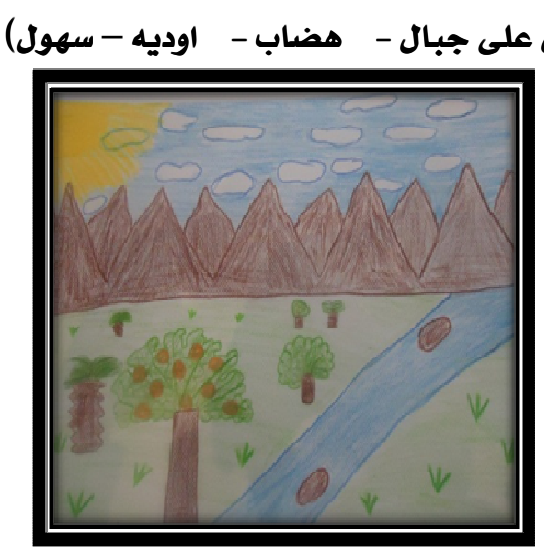

شكل رقم(ج)

رهف حسن

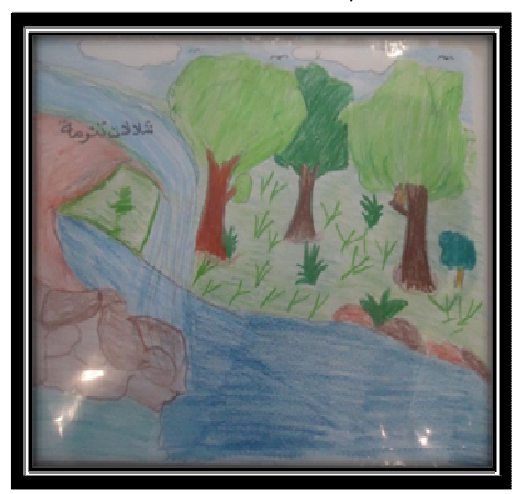

شكل رقم (ه) (10)

فيصل علي

أظهرت النتائج أن الأطفال الذكور كانوا أكثر رسماً للهضاب والجبال والأودية من الإناث

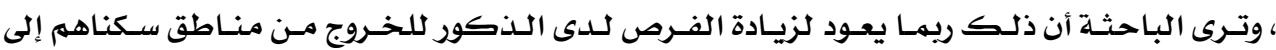

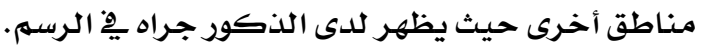
ثاثثاً: الرسومات التي تكررت بنسب متقاربة لدى الجنسين

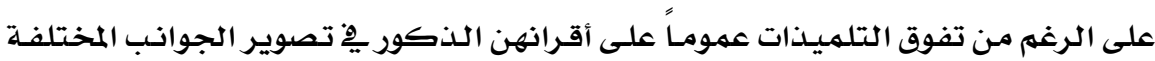

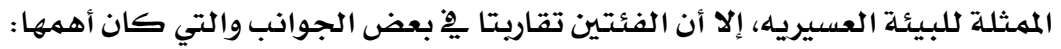
معالم من صنع الانسان (مباني تراثية -ابار- مزارع)

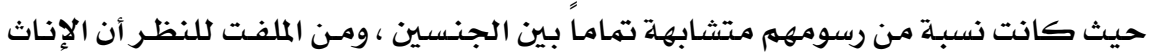

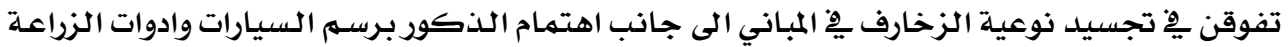

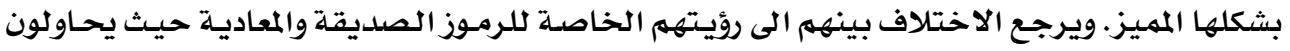

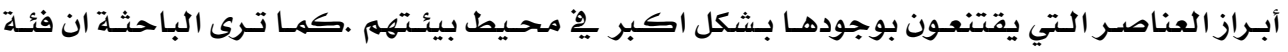

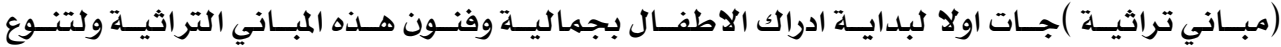
انهاط بنائها. 


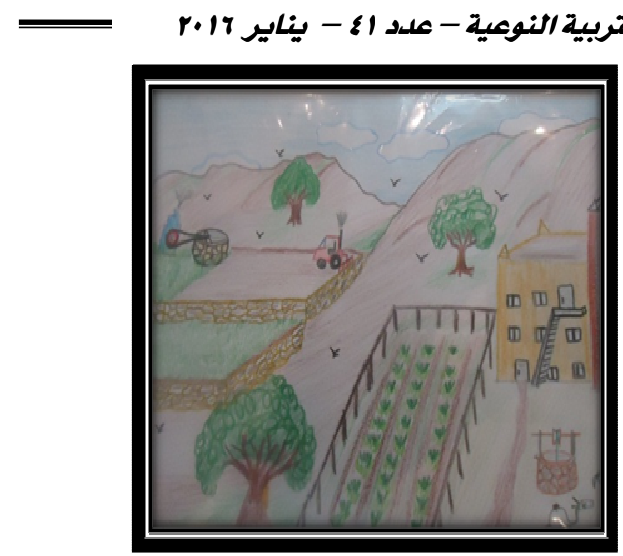

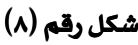

بندر عايض

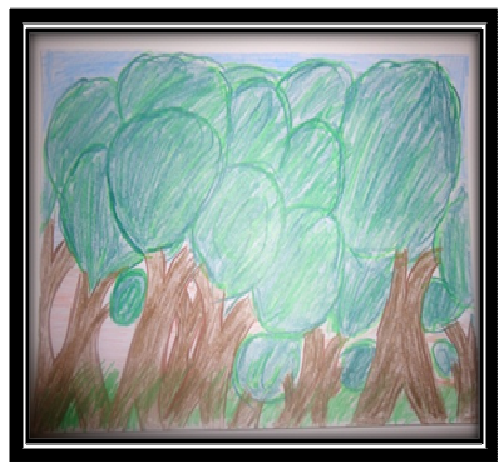

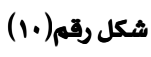

مرام علي

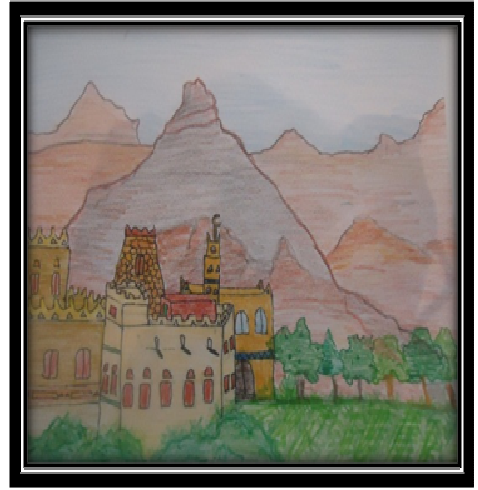

شكل رقم(v)

طيف محمد

رسم النباتات (موجز شكلي يدل على الغابات)

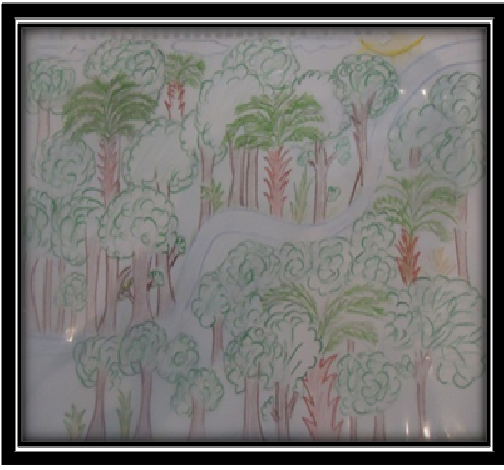

شكل رقم(9) مجمد مal)

محمد مصلح

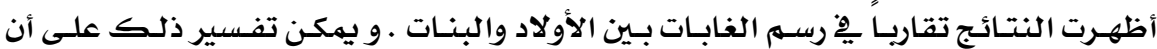

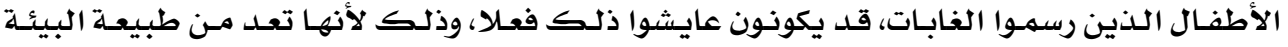

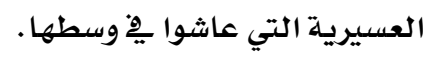


بناء على النتائج التي توصلت اليها البحـث ، توصسي الباحثة ببعض التوصيات والتي يمكن

$$
\text { تحديدها فيما يلي : }
$$

ا- بناء على نتائج البحث فانه بآلامكن اعتبار رسوم الاطفال مدخلا لمعرفة ملدى تأثير البيئة

$$
\text { على الطفل. }
$$

ץ- على اولياء الامور ومعلمي التربية الفنية تعزيز جانب الحفاظ على التراث المحلي لدى اطفال

المرحلة الابتدائية.

r- تقترح الباحثة اجراء دراسات على تأثير البيئة على المراحل المتبقية مـن مراحل نهو التعبير

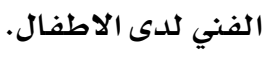

ع- تقترح الباحثة اقامت متاحف تعليميلة خاصلة بالتراث متاحة لطلاب المراحل الدراسية، وذلك الكئل

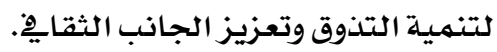

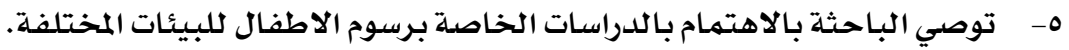

المراجع:-

$$
\text { ا- المججم الوسيط، مكتبـة الشروق الدولية }
$$

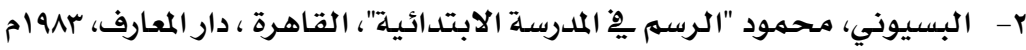

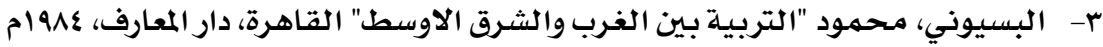
ع- البسيوني، محمود "سيكولوجية رسوم الاطفال" القاهرة، دار المعارف ، 1910 ام

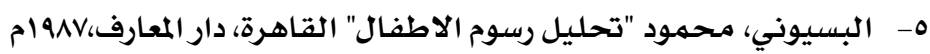

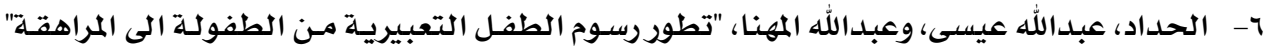

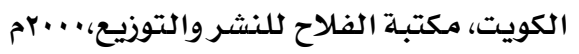

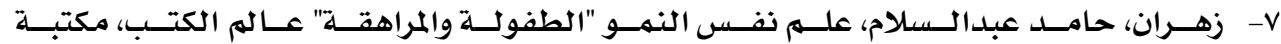

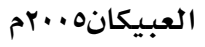

^- زيدان، محمد مصطفى "النمو النفسي للطفل والمراهق" جدة، دار الشروق •199م

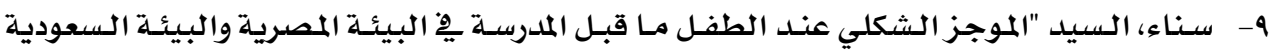

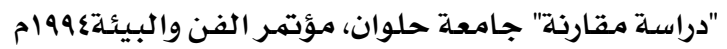

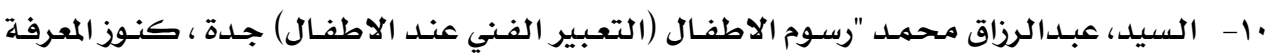

$$
\text { بلدون تاريخ }
$$

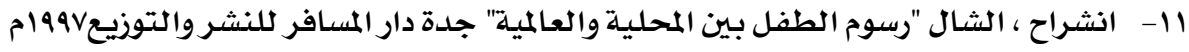

rا- الشريعي، احمد البدوي "جغرافية العمران الريفي" مصر، دار الفكر العربيو999ام 


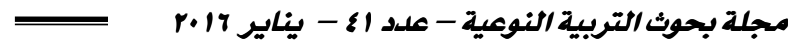

با- الشهراني، علـي مـرزوق "العنـاصـر الفنيـة والجماليـة للعهـارة التقليديـة بهنطقـة عسير" مكــة

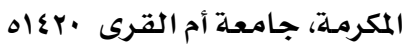

أ- عبدالعزيز، مصطفى محمد "سيكولوجية التعبير الفني عند الاطفال" القاهرة، مكتبـة الانجلو

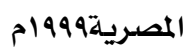

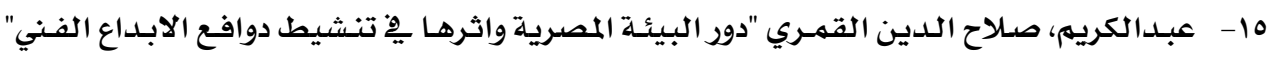

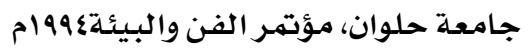

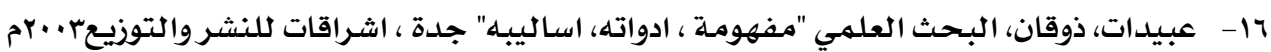

IV

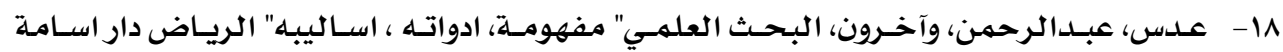

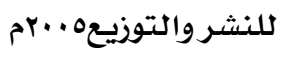

19- العدوى، منال محمدي طه "فنون الأطفال وتطورها" الرياض دار النشر الدوليr. .بrم

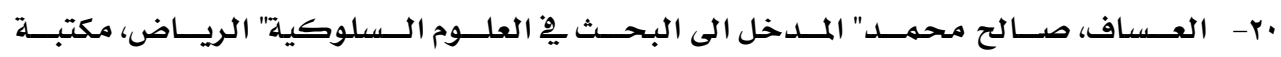

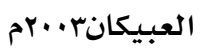

ابr- القحطـاني، عبــالله سـالهم "الـتراث الشعبي يِّ منطقـة عسبير" الريـاض ادارة المطبوعـات بـوزارة

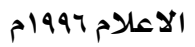

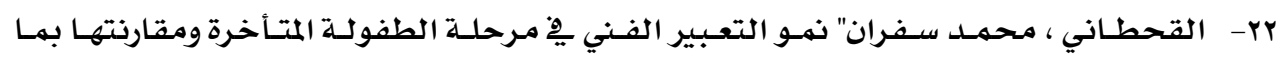

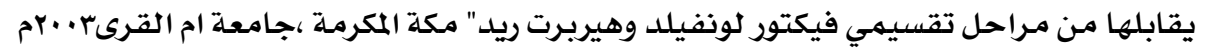

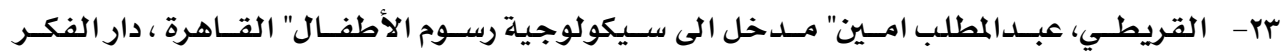

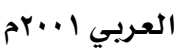

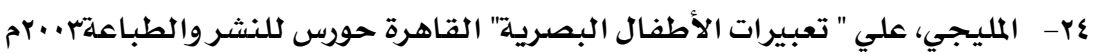

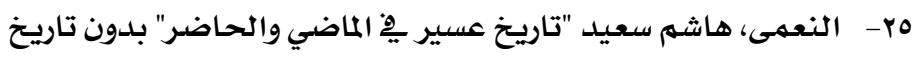

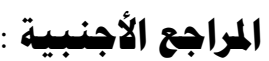

26-Incday, Michael(2001) : Children and Their Art Orlando: Fl,Harcourt College Publishers

27-Markus,janet (2002): Student Assessment And Evaluation In Studio Art .

PhD .Dissertation ,University Of Toronto, Canada .

28-Tomaselli, Linda ( 2013 ) : An Investigation Of The Development And Use

Of Memory In Representational Drawings Made By Children 5 29- 12 Years.

PhD . Columbia University, America . 


\section{The Impact Of The Environment On Children's Drawings In Asir (Comparative Study)}

Amal Abdullah Al Shehri*

\section{Abstract}

The objective of the research is to identify the components of an environment of Asir and appearing in children's art expressions on stage trying to realistic expression, They also aim to identify the impact of environment Asir expressions technical stage children try realistic expression, The objective is also to show the differences between categories of elements of an environment of Asir in male and female children in years try realistic expression, Search results may be summarized as follows:

1. the researcher found that the impact of the environment of Asir on children try realistic expression came by $(30,2 \%)$ This percentage is considered slim, Where the researcher believes that the reason for this is due to the fact that the study sample of civil society.

2. the researcher noted that item (climate) and (terrain) has appeared significantly less items (folklore) and (animal) in children's drawings on the stage to try realistic expression.

3. through the analysis of children's drawings on the stage to try realistic expression observed that fifth graders (10-11 years) are the most influenced by elements of the environment of Asir.

4. the researcher noticed that most kids who sample drawing environment of Asir and photographed various aspects and not disappear any component of their drawings, It was the order of things you painted (topography, climate, man-made landmarks, Botany, folklore, animal.(

5. the researcher observed a clear superiority to females because their drawings full of function elements on environment of Asir, The researcher explained that the reason for the superiority of females to males in their expression, and depicted various aspects of nature

${ }^{*}$ Lecturer, Faculty of education Najran University 